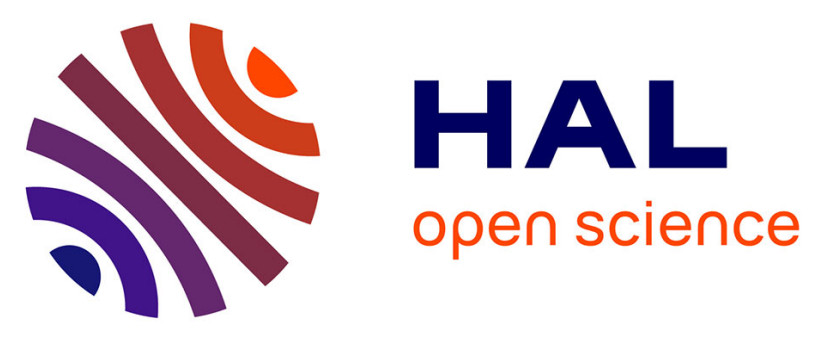

\title{
Ruthenium p-cymene iminophosphonamide complexes: Activation under basic conditions and transfer hydrogenation catalysis
}

Iana Sinopalnikova, Tatyana A. Peganova, N. V. Belkova, Éric Deydier, Jean-Claude Daran, E. S. Shubina, Alexander M. Kalsin, Rinaldo Poli

\section{To cite this version:}

Iana Sinopalnikova, Tatyana A. Peganova, N. V. Belkova, Éric Deydier, Jean-Claude Daran, et al.. Ruthenium p-cymene iminophosphonamide complexes: Activation under basic conditions and transfer hydrogenation catalysis. European Journal of Inorganic Chemistry, 2018, 2018 (20-21), pp.2285-2299. 10.1002/ejic.201701344 . hal-01954087

\section{HAL Id: hal-01954087 \\ https://hal.science/hal-01954087}

Submitted on 1 Mar 2021

HAL is a multi-disciplinary open access archive for the deposit and dissemination of scientific research documents, whether they are published or not. The documents may come from teaching and research institutions in France or abroad, or from public or private research centers.
L'archive ouverte pluridisciplinaire $\mathbf{H A L}$, est destinée au dépôt et à la diffusion de documents scientifiques de niveau recherche, publiés ou non, émanant des établissements d'enseignement et de recherche français ou étrangers, des laboratoires publics ou privés. 


\title{
Ruthenium p-cymene iminophosphonamide complexes: activation under basic conditions and transfer hydrogenation
} catalysis

\author{
Iana S. Sinopalnikova, ${ }^{[a, b]}$ Tatyana A. Peganova, ${ }^{[b]}$ Natalia V. Belkova, ${ }^{[b]}$ Eric Deydier, ${ }^{[a]}$ Jean-Claude \\ Daran, ${ }^{[a]}$ Elena S. Shubina, ${ }^{[b]}$ Alexander M. Kalsin, ${ }^{[b]}$ and Rinaldo Poli ${ }^{*[a, c]}$ \\ With best wishes of continued success to the European Journal of Inorganic Chemistry
}

\begin{abstract}
Complex $\left[\left(\eta^{6}-\right.\right.$ Cym $\left.) \operatorname{RuCl}(\mathbf{N P N})\right]\{$ Cym $=p$-cymene; $\mathbf{N P N}=$ $\left.(p-T o I N)_{2} \mathrm{PPh}_{2}\right\}$ (1) yields a thermally sensitive hydride derivative $\left[\left(\eta^{6}-\right.\right.$ Cym)RuH(NPN)] (2) by reaction with $\mathrm{PrOH}$ in the presence of a strong base, via an observable isopropoxide intermediate $\left[\left(\eta^{6}-\right.\right.$ Cym) $\mathrm{Ru}(\mathrm{O} / \mathrm{Pr})(\mathbf{N P N})]$ (3), or with $\mathrm{NaBHEt}_{3}$ in THF. Partial conversion also occurs in $\mathrm{PrOH}$ in the absence of base. 2 is stabilized by dihydrogen bonding with isopropanol, but attempts to isolate it induce isomerization by hydride migration to a ring $\mathrm{CH}$ position to yield a 16electron cyclohexadienyl derivative $\left[\left\{\eta^{5}-p-\mathrm{C}_{6} \mathrm{H}_{5}(\mathrm{Me})(\mathrm{Pr})\right\} \mathrm{Ru}(\mathrm{NPN})\right]$, which has been crystallographically characterized as a disordered mixture of two regioisomers $\left(\mathbf{4} / \mathbf{4}^{\prime}\right)$. Complex 2 is able to release $\mathrm{H}_{2}$ upon treatment with medium strength proton donors (fluorinated alcohols), but also slowly with $\mathbb{P r O H} .2$ is an active catalyst for the transfer hydrogenation of acetophenone to phenylethanol in isopropanol. The catalytic transformation is first order in acetophenone and first order in catalyst, with $k=117 \pm 10 \mathrm{M}^{-1} \mathrm{~h}^{-1}$ at $40^{\circ} \mathrm{C}$. The temperature dependence of the rate constant $\left(25-80^{\circ} \mathrm{C}\right)$ gave the activation parameters $\Delta H^{*}=9.6 \pm 1.3 \mathrm{kcal} \mathrm{mol}^{-1}$ and $\Delta S^{\ddagger}=-$ $31 \pm 4 \mathrm{cal} \mathrm{mol}^{-1} \mathrm{~K}^{-1}$. DFT calculations have validated the slow isomerization of 2 to $\mathbf{4} \mathbf{4}^{\prime}$ ' (high energy TS), the preference of the cyclohexadienyl system for $\mathbf{4} / \mathbf{4}^{\prime}$ relative to the other isomers $4^{\mathrm{Me}}$ and $4^{\mathrm{Pr}}$, where the hydride has migrated to the $\mathrm{CMe}$ or $\mathrm{CiPr}$ position, and suggest that the hydrogen transfer mechanism involves outer sphere hydride transfer to the ketone substrate with $\mathrm{H}$-bonding assistance of isopropanol to yield a $\sigma$-complex intermediate $\left[\left(\eta^{6}-\mathrm{Cym}\right) \mathrm{Ru}^{+}(\mathbf{N P N})\{\mathrm{H}-\right.$ $\left.\mathrm{C}(\mathrm{Me})(\mathrm{Ph}) \mathrm{O}^{-}\right\}$.
\end{abstract}

\section{Introduction}

During the last two decades catalytic transfer hydrogenation (TH) of ketones has become a powerful method for the production of

[a] I. S. Sinopalnikova, E. Deydier, J.-C. Daran, R. Poli CNRS, Laboratoire de Chimie de Coordination, Université de Toulouse, UPS, INPT

205 Route de Narbonne, 31077 Toulouse Cedex 4, France

E-mail: rinaldo.poli@lcc-toulouse.fr https://www.lcc-toulouse.fr/auteur185.html

[b] T. A. Peganova, N. V. Belkova, A. M. Kalsin

A.N. Nesmeyanov Institute of Organoelement Compounds Russian Academy of Sciences

28 Vavilov str., 119991 Moscow, Russia

[a] R. Poli

Institut Universitaire de France

1, rue Descartes, 75231 Paris Cedex 05, France

Supporting information for this article is given via a link at the end of chiral secondary alcohols featuring high chemo- and enantioselectivity under mild conditions. A number of highly efficient ruthenium-based catalysts have been developed to date, particularly $\left[\left(\eta^{6} \text {-arene }\right) \mathrm{RuCl}\left(\mathrm{H}_{2} \mathrm{NCHPhCHPhNTs}\right)\right]^{[1]}$ by Noyori and Ikariya (A), cyclometallated complexes with $\kappa^{2}-\mathrm{PC}$ and $\kappa^{3}$. $\mathrm{CNN}$ ligands cis-[RuCl $2\left(0-\mathrm{CH}_{2} \mathrm{C}_{6} \mathrm{H}_{4} \mathrm{PPh}_{2}\right)($ aminomethylpyridine) $]^{[2]}(\mathrm{B})$ and $[\mathrm{RuCl}(\mathrm{PP})(\mathrm{CNN})]^{[3]}(\mathbf{C})$ by Baratta, and zwitterionic complexes $\left[\left(\eta^{6}\right.\right.$-arene $\left.) \operatorname{RuCl}\left(\kappa^{2}-\mathrm{P}, \mathrm{N}\right)\right]$ prepared from 1,2-substituted indenide with donor P,N groups ${ }^{[4]}$ by Stradiotto (D). The mechanism of ketone transfer hydrogenation catalyzed by Noyori complexes has been scrutinized to discover that the origin of the high enantioselectivity is the ancillary $\mathrm{NH}$-ligand assistance in the hydrogenation step, giving a highly ordered transition state..$^{[5]}$ The high enantioselectivities demonstrated by cyclometalated CNN ruthenium complexes were also attributed to the operation of $\mathrm{NH}$ bifunctional catalysis, although an alternative pathway via an alkoxide active species could not be excluded. ${ }^{[2-3]}$ These three catalysts (A, B and $\mathbf{C}$ ) involve the corresponding mono-hydrides $\mathrm{Ru}-\mathrm{H}$ as the active species in the catalytic cycle. In sharp contrast, the catalysis by the zwitterionic $\mathrm{P}, \mathrm{N}$-indenide complex, which is unable to build ancillary $\mathrm{Ru}-\mathrm{NH}$ interactions, proceeds via an undetermined mechanism, while the corresponding $\mathrm{Ru}-\mathrm{H}$ species is completely inactive and its formation represents the catalyst deactivation pathway. ${ }^{[4]}$ In this regard, we were interested in employing another type of zwitterionic ruthenium complex, having an iminophosphonamide (NPN ${ }^{[6]}$ ligand $(\mathbf{E})$, for the reduction of ketones under transfer hydrogenation conditions. The only other ruthenium iminophosphonamide complex known before our studies, $\quad\left[\left(\eta^{6}-\mathrm{Cym}\right) \mathrm{Ru}\left\{\left(\mathrm{NH}^{\prime} \mathrm{Pr}\right)_{2} \mathrm{PPh}\left(\mathrm{NH}^{\mathrm{P} P r}\right)\right\}\right]\left(\mathrm{BPh}_{4}\right) \quad(\mathrm{Cym}=p-$ cymene, $\left.\mathrm{C}_{6} \mathrm{H}_{4}-1-i-\mathrm{Pr}-4-\mathrm{Me}\right)$, was reported to be inactive in ketone transfer hydrogenation. ${ }^{[7]}$ This is not so surprising, as this $16 \bar{e}$ complex is not able to add ligands except for strong $\pi$-acceptors like $\mathrm{CO}$ and $\mathrm{CN}^{-}$. We have shown that the $16 \overline{\mathrm{e}}$ ruthenium iminophosphonamides complexes are very stable species due to strong $\sigma, \pi$-donating ability of the NPN ligand. ${ }^{[8]}$ At the same time, the high negative charges located at the nitrogen atoms of the NPN ligand render the corresponding $18 \overline{\mathrm{e}}$ ruthenium iminophosphonamides coordinatively labile and reactive, as we demonstrated by the facile insertion of the $\mathrm{CO}$ into the $\mathrm{Ru}-\mathrm{N}$ bond in the $\left[\left(\mathrm{C}_{6} \mathrm{Me}_{6}\right) \mathrm{Ru}(\mathrm{CO})\left\{(\mathrm{NMe})_{2} \mathrm{PPh}_{2}\right\}\right]\left(\mathrm{PF}_{6}\right)$ complex. ${ }^{[9]}$ Hence, the $18 \overline{\mathrm{e}}$ ruthenium iminophosphonamide complexes, being isoelectronic to Noyori's catalysts, are promising for the catalyzed $\mathrm{TH}$ of ketones. 


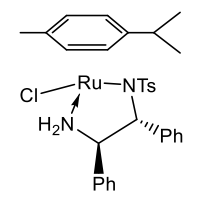

A<smiles></smiles>

B

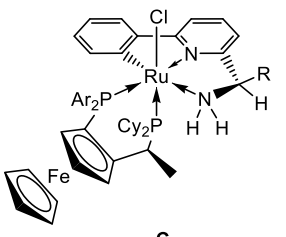

c

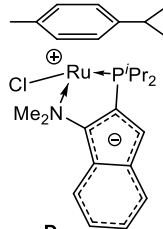

D

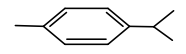

$\mathrm{Cl}-\mathrm{Ru}^{\mathrm{Ru}}-\mathrm{N}-\mathrm{R}^{\prime}$

$R^{\prime} \stackrel{N}{N} \underset{\oplus}{P R_{2}}$

E

In this paper we report the transfer hydrogenation of a model ketone (acetophenone) with isopropanol catalyzed by a specific $\left[\left(\eta^{6}-\right.\right.$ Cym $\left.) \mathrm{RuCl}(\mathbf{N P N})\right]$ complex with $\mathbf{N P N}=\left(p-\mathrm{ToIN}_{2} \mathrm{PPh}_{2}(\mathbf{1})^{[9]}\right.$ under various conditions, including kinetic studies and the identification of intermediates and an off-loop species. A DFT study of the proposed catalytic cycle is also presented.

\section{Results and Discussion}

\section{(a) Generation and properties of $\left[\left(\eta^{6}-\mathrm{Cym}\right) \mathrm{Ru}(\mathrm{NPN}) \mathrm{H}\right]$}

Complex $\mathbf{1}$ is quite soluble in apolar solvents such as benzene and only sparingly soluble in $\mathrm{PrOH}$. It is characterized by a ${ }^{31} \mathrm{P}$ resonance at $\delta 42.9$ in $\mathrm{C}_{6} \mathrm{D}_{6}$ and 44.6 in $\mathrm{PrOH}$.. Treatment of 1 with the strong base bis(trimethylsilyl)amide, $\mathrm{Na}\left[\mathrm{N}\left(\mathrm{SiMe}_{3}\right)_{2}\right]$ (NaHMDS), in $\mathrm{C}_{6} \mathrm{D}_{6}$ in the presence of $\mathrm{PrOH}$ led to the rapid and rather selective generation of the hydride complex $\left[\left(n^{6}-\right.\right.$ Cym) $\mathrm{Ru}(\mathrm{NPN}) \mathrm{H}]$ (2) at room temperature. The most characteristic NMR resonances of 2 are a signal at $\delta 33.2$ in the ${ }^{31} \mathrm{P}\left\{{ }^{1} \mathrm{H}\right\}$ spectrum and the hydride signal at $\delta-3.1$ in the ${ }^{1} \mathrm{H}$ spectrum, but all other ligand nuclei have also been identified in the ${ }^{1} \mathrm{H}$ and ${ }^{13} \mathrm{C}$ spectra, the assignment being aided by $\mathrm{HMQC}\left({ }^{1} \mathrm{H}-\right.$ $\left.{ }^{13} \mathrm{C}\right)$ and ${ }^{13} \mathrm{C}\left(\mathrm{JMOD}-{ }^{1} \mathrm{H}\right)$ experiments. Both ${ }^{1} \mathrm{H}$ and ${ }^{13} \mathrm{C}$ spectra also reveal the simultaneous formation of acetone (see $\mathrm{SI}$, Figures $\mathrm{S} 1$ and S2). Monitoring this reaction by ${ }^{31} \mathrm{P}\left\{{ }^{1} \mathrm{H}\right\} \mathrm{NMR}$ (Figure 1) shows the presence of an intermediate characterized by a resonance at $\delta 38.5$, which we believe corresponds to the isopropoxide complex $\left[\left(\eta^{6}-\mathrm{Cym}\right) \mathrm{Ru}(\mathbf{N P N})(\mathrm{O} i \mathrm{Pr})\right](\mathbf{3})$, see Scheme 1. This intermediate accumulates in the first minutes, then rapidly decreases and almost completely disappears after $30 \mathrm{~min}$.

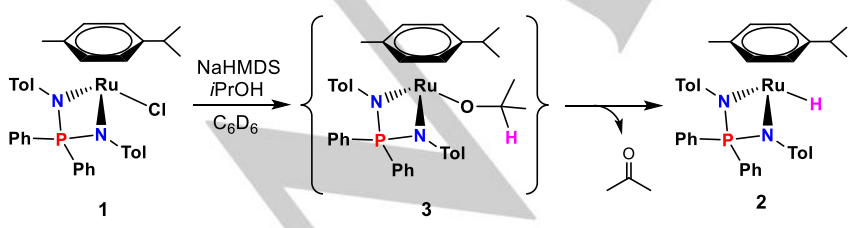

Scheme 1. Generation of hydride 2 from 1
The solution of $\mathbf{2}$ is also contaminated by very small amounts of the phosphine oxide $\mathrm{Ph}_{2} \mathrm{P}(\mathrm{O}) \mathrm{NH}(p$-Tol) (NPO, $\delta$ 16.9) and the free protonated NPN ligand $(p-\mathrm{Tol}) \mathrm{NPPh}_{2} \mathrm{NH}(p-\mathrm{Tol})(\mathbf{N P N H})(\delta-$ 5.5, cf. $-3.5^{[8]}$ in $\left.\mathrm{CDCl}_{3}\right)$. Aminophosphine oxides $\mathrm{Ph}_{2} \mathrm{P}(\mathrm{O}) \mathrm{NHAr}$ have been shown to result from hydrolytic degradation of diaminophosphonium salts, $\mathrm{Ph}_{2} \mathrm{P}(\mathrm{NHAr})_{2}{ }^{+}$, and iminophosphonamines, $\mathrm{Ph}_{2} \mathrm{P}(\mathrm{NAr})(\mathrm{NHAr})$; the related compound $\mathrm{Ph}_{2} \mathrm{P}(\mathrm{O}) \mathrm{NH}(2,6-$ $\mathrm{C}_{6} \mathrm{H}_{3} \mathrm{Me}_{2}$ ) was shown to exhibit a ${ }^{31} \mathrm{P} N M R$ resonance at $\delta 20.8 .^{[10]}$ Compound 2 slowly decomposes at room temperature (see Figure S3 for a longer timescale monitoring) and even faster upon warming. This degradation leads to the increase of the NPO and NPNH amounts, to the generation of two isomers of $\mathbf{2}$ with resonances at $\delta 50.6(4)$ and 51.1 (4'), and two additional species characterized by ${ }^{31} \mathrm{P}\left\{{ }^{1} \mathrm{H}\right\}$ resonances at $\delta 27.4$ and 26.2 (5 and $\left.\mathbf{5}^{\prime}\right)$, which slowly accumulate within days (Figure S3) or upon attempt to isolate 2 (Figure S4). In $\mathbf{4}$ and $\mathbf{4}$ ', the hydride has migrated to the cymene ring to generate a cyclohexadienyl ligand, $\left[\mathrm{fn}^{5}\right.$ $\left.\left.\mathrm{C}_{6} \mathrm{H}_{5}(\mathrm{Me})(\mathrm{Pr})\right\} \mathrm{Ru}(\mathbf{N P N})\right]$; further details on these two compounds will be shown below. Species $\mathbf{5}$ and $\mathbf{5}$ ' are asymmetric hydride complexes (see more details in the SI and further discussion below).

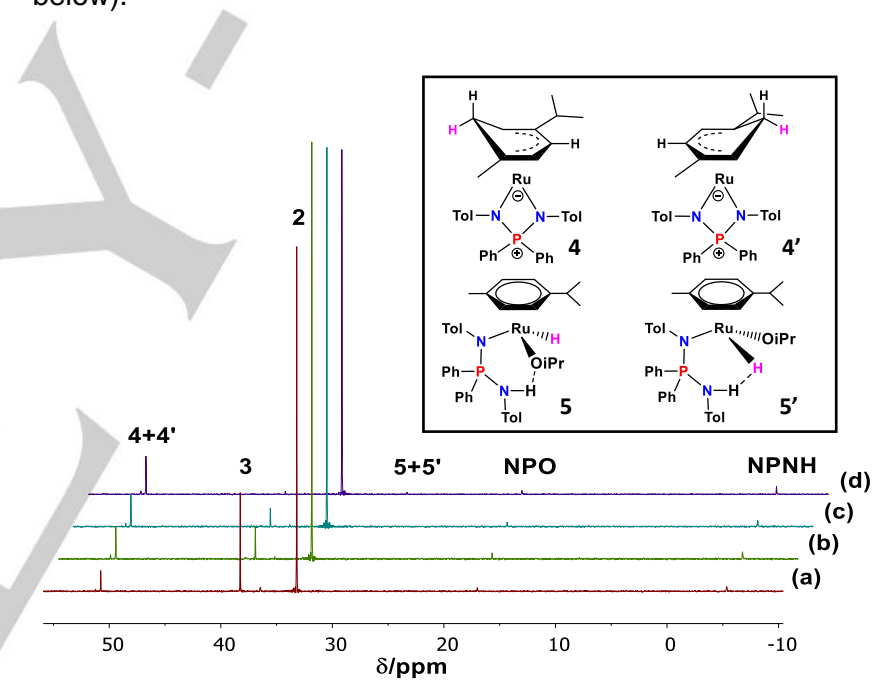

Figure 1. ${ }^{31} \mathrm{P}\left\{{ }^{1} \mathrm{H}\right\}$ NMR monitoring of the generation of 2 at room temperature: $0.5 \mathrm{~mL}$ of $\mathrm{C}_{6} \mathrm{D}_{6}, 13 \mathrm{mg}$ of $1(0.02 \mathrm{mmol}), 60 \mu \mathrm{L}$ of $\mathrm{PrOH}(\mathrm{PrOH} / \mathbf{1}=40), 15 \mu \mathrm{L}$ of NaHDMS (2 M in THF; HMDS/1 = 1.5). (a) 5 min from sample preparation, (b) $13 \mathrm{~min},(\mathrm{c}) 20 \mathrm{~min},(\mathrm{~d}) 30 \mathrm{~min}$

The same treatment of 1 with $\mathrm{PrOH}$ in $\mathrm{C}_{6} \mathrm{D}_{6}$ in the presence of a weaker base (DBU) led only to a slower and partial generation of $2(60 \%$ yield in 30 minutes at room temperature), which decomposes upon heating for $2 \mathrm{~h}$ at $60^{\circ} \mathrm{C}$ to form mainly NPNH $(\delta-5.3)$ and NPO $(\delta$ 17.9). A minor amount of the same intermediate observed upon addition of NaHMDS $(3, \delta 38.4)$ is also formed (see ${ }^{31} \mathrm{P}\left\{{ }^{1} \mathrm{H}\right\}$ monitoring in Figure S5), but both 2 and 3 further decrease and nearly disappear after prolonged heating.

Interestingly, a similar trend is also observed upon heating the precursor complex $\mathbf{1}$ in the presence of $\mathrm{PrOH}$ and in the absence of base. In neat $\mathrm{PrOH}$, long-term heating at $80^{\circ} \mathrm{C}$ leads to complete dissolution with generation of a new species characterized by a ${ }^{31} \mathrm{P}\left\{{ }^{1} \mathrm{H}\right\}$ resonance at $\delta 32.9$, attributed to the 
hydride compound 2 (Figure S6). The shift relative to the resonance observed in $\mathrm{C}_{6} \mathrm{D}_{6}$ is caused by $\mathrm{H}$-bonding with $\mathrm{PrOH}$ (vide infra). The spectrum also contains resonances of residual $\mathbf{1}$, phosphine oxide NPO $(\delta 19.2)$ and free protonated ligand NPNH (broad resonance at 4.0). Treatment with smaller amounts of PrOH in $\mathrm{C}_{6} \mathrm{D}_{6}$ and warming to $60^{\circ} \mathrm{C}$ equally led to the slow generation of 2 ( $\delta 33.0)$ and the same decomposition products NPO ( $\delta$ 17.9) and NPNH (initially sharp at $\delta-5.3$ and later broader and slightly downfield shifted to -3.9), see Figure S7. The chemical shift variability and width of the NPNH resonance indicate the presence of proton exchange equilibria (the ${ }^{31} \mathrm{P} N \mathrm{NMR}$ resonance of the protonation product $\left[\mathrm{Ph}_{2} \mathrm{P}\left(\mathrm{NH}-p-\mathrm{C}_{6} \mathrm{H}_{4} \mathrm{Me}\right)_{2}\right] \mathrm{Br}$ is reported at $\left.\delta 28.0^{[10]}\right)$. The ${ }^{1} \mathrm{H}$ NMR spectrum shows concomitantly the presence of the hydride resonance of $\mathbf{1}$ at $\delta$ 3.1, which is however evident only initially while the NPNH resonance is small and sharp (see below for a rationalization). The ${ }^{31} \mathrm{P}$ NMR spectrum also shows the growth of an additional sharp resonance at $\delta 40.4$, which seems attributable to the isopropoxide complex 3 (cf. $\delta 38.5$ in Figure 1). It would thus appear that $\mathbf{3}$, generated from $\mathbf{1}$ and PrO- $^{-}$in a strongly basic medium, quantitatively releases acetone (observed by NMR) to yield 2 at room temperature, whereas 2 can react with $\mathrm{PrOH}$ upon warming in the absence of base to regenerate $\mathbf{3}$ (and presumably release $\mathrm{H}_{2}$ ). The latter proposition is further suggested by the results of similar experiments with more acidic alcohols (vide infra).

Additional NMR spectra have been recorded for compound 2 in the presence of variable amounts of $\mathrm{PrOH}$ and of the stronger proton donor trifluoroethanol (TFE), see Table 1. The results show quite clearly that the hydride resonance is affected by the establishment of a "dihydrogen bond", ${ }^{[11]}$ namely an $\mathrm{H}$-bond between the alcohol as a proton donor $(\mathrm{HA})$ and the hydride ligand of $\mathbf{2}$ as a proton acceptor, [ $\left.\left.\eta^{6}-\mathrm{Cym}\right) \mathrm{Ru}(\mathbf{N P N}) \mathrm{H} \cdots \mathrm{HA}\right]$, resulting in greater upfield shifts when the proton donor is either stronger (cf. entries 3 and 6) or present in greater amounts (entries 2-5). As expected, this effect is more notable on the ${ }^{1} \mathrm{H}$ hydride resonance and much less on the ${ }^{31} \mathrm{P}$ resonance. Formation of 2. $\mathrm{IPrOH}$ can be considered as a prerequisite for the observed $\mathrm{H}_{2}$ evolution from 2 and $\mathrm{PrOH}$, to yield 3..$^{[11 \mathrm{~b}]}$ The IR spectrum of a $\mathrm{C}_{6} \mathrm{D}_{6}$ solution of the hydride complex 2 , obtained as described above with $\mathrm{NaHMDS} / \mathrm{PrOH}$, shows a well resolved $\mathrm{v}(\mathrm{RuH})$ band at $1882 \mathrm{~cm}^{-1}$ and the bands of residual $\operatorname{PrOH}(\mathrm{v}(\mathrm{OH})$ $\left.=3604 \mathrm{~cm}^{-1}\right)$ as well as of acetone $\left(\mathrm{v}(\mathrm{CO})=1716 \mathrm{~cm}^{-1}\right)$. Upon addition of a nearly equimolar amount of acetophenone the $\mathrm{v}(\mathrm{RuH})$ band shifts to $1887 \mathrm{~cm}^{-1}$. This is probably the result of dihydrogen bond disruption caused by the formation of the stronger and competing $\mathrm{PhMeCO}$...HOPr hydrogen bond (Figure S8).

The presence of acetone has no effect on the ${ }^{1} \mathrm{H}$ and ${ }^{31} \mathrm{P}$ resonances of $\mathbf{2}$ when added in small quantities. A large excess (Table 1, entry 8), on the other hand, leads to displacement of the ${ }^{31} \mathrm{P}$ resonance to lower fields and to a strong upfield shift of the hydride ${ }^{1} \mathrm{H}$ resonance. This phenomenon can be rationalized with the establishment of a hydride transfer equilibrium, probably involving an $18 \overline{\mathrm{e}} \sigma$-complex [( $p$-Cym) $\left.\mathrm{Ru}^{+}(\mathbf{N P N}) \cdots \mathrm{HCMe}_{2} \mathrm{O}^{-}\right](6)$. Such a process should lead to increased shielding for the hydride ligand, similar to dihydrogen bond. ${ }^{[12]}$ Complex 6 is a presumed intermediate on the way to the isopropoxide complex 3. A rapid equilibrium between 2 and 3 is excluded because both compounds are independently observed under other conditions (e.g. Figure 1, Figure S5 and Figure S7), thus their interchange is slow on the NMR timescale.

Table 1. NMR resonances for solutions of $\left[\left(\eta^{6}-\mathrm{Cym}\right) \mathrm{Ru}(\mathrm{NPN}) \mathrm{H}\right](2)$ in the presence of alcohols. ${ }^{[a]}$

\begin{tabular}{lllll}
\hline entry & solvent & additive (amount) & ${ }^{31} \mathrm{P}, \mathrm{ppm}$ & ${ }^{1} \mathrm{H}, \mathrm{ppm}$ \\
\hline 1 & $\mathrm{C}_{6} \mathrm{D}_{6}$ & & 33.2 & -2.96 \\
2 & $\mathrm{C}_{6} \mathrm{D}_{6}$ & iPrOH (2 equiv) & 33.2 & -2.98 \\
3 & $\mathrm{C}_{6} \mathrm{D}_{6}$ & iPrOH (10 equiv) & 33.2 & -3.01 \\
4 & $\mathrm{C}_{6} \mathrm{D}_{6}$ & iPrOH (40 equiv) & 33.2 & -3.07 \\
5 & $\mathrm{PrOH}^{[\mathrm{b}]}$ & & 32.9 & -3.14 \\
6 & $\mathrm{C}_{6} \mathrm{D}_{6}$ & $\mathrm{TFE}(10$ equiv) & 33.4 & -3.16 \\
7 & $\mathrm{C}_{6} \mathrm{D}_{6}$ & Acetone (10 equiv) & 33.2 & -2.98 \\
8 & $\mathrm{CD}_{3} \mathrm{COCD}_{3}$ & & 33.9 & -3.53 \\
\hline
\end{tabular}

[a] For all entries except 6 , the compound was generated in situ in $\mathrm{C}_{6} \mathrm{D}_{6}$ from 1, NaHMDS and $\mathrm{PrOH}$ as described in the experimental section. [b] Instrument lock with a $\mathrm{C}_{6} \mathrm{D}_{6}$ capillary. [c] Experiment run starting from a solution of 4/4' (vide infra).

On the basis of all the above evidence, the evolution of $\mathbf{1}$ in isopropanol can be summarized as follows (Scheme 2). In the absence of base at elevated temperatures, isopropanol reversibly substitutes a chloride ligand in $\mathbf{1}$, presumably following selfdissociation via the $16 \bar{e}$ complex [7] Cl and the 18ē isopropanol adduct $\mathbf{8}$, the latter two compounds being probably present in small and unobservable equilibrium amounts. The generation of these two ionic intermediates should be facilitated by the polarity of isopropanol. The involvement of the $16 \bar{e}[7] \mathrm{Cl}$ complex as intermediate in the dissociative chloride-exchange process in polar solvents has previously been established and a salt of [7] ${ }^{+}$ with the non-coordinating $\mathrm{PF}_{6}{ }^{-}$anion has been fully characterized. ${ }^{[9]}$ Formation of the observed hydride product 2 requires deprotonation of $\mathbf{8}$ to generate 3 followed by $\beta-\mathrm{H}$ elimination from the isopropoxide ligand. When an external base is not present, generation of a base may be imagined by decomposition of $\mathbf{2}$ via slow alcoholysis of one $\mathrm{Ru}-\mathrm{N}$ bond and generation of the observed asymmetric hydride intermediates $\mathbf{5}$ and 5', followed by NPNH decoordination, presumably with solvent assistance, to yield a putative solvated isopropoxide complex 9 . This product has not been directly detected, but we note that related $\left[(\text { arene }) \mathrm{Ru}(\mu-\mathrm{OR})_{3} \mathrm{Ru}(\text { arene })\right]^{+}$complexes have been described in the literature. ${ }^{[13]}$ Although we have shown earlier that even weak bases such as $\mathrm{Et}_{2} \mathrm{NH}$ can deprotonate NPNH during the synthesis of $1,^{[8-9]}$ this acid-base equilibrium is certainly solvent-dependent and the reverse process of NPN ligand decoordination from the ruthenium atom may become favorable in polar protic solvents. The formation of $\mathbf{3}$ is accompanied by the generation of the diaminophosphonium salt $\left[\mathrm{Ph}_{2} \mathrm{P}(\mathrm{NH}-p-\mathrm{Tol})_{2}\right]^{+} \mathrm{Cl}^{-}\left(\mathrm{NPNH}_{2}{ }^{+} \mathbf{C l}{ }^{-}\right)$, which can undergo rapid and 


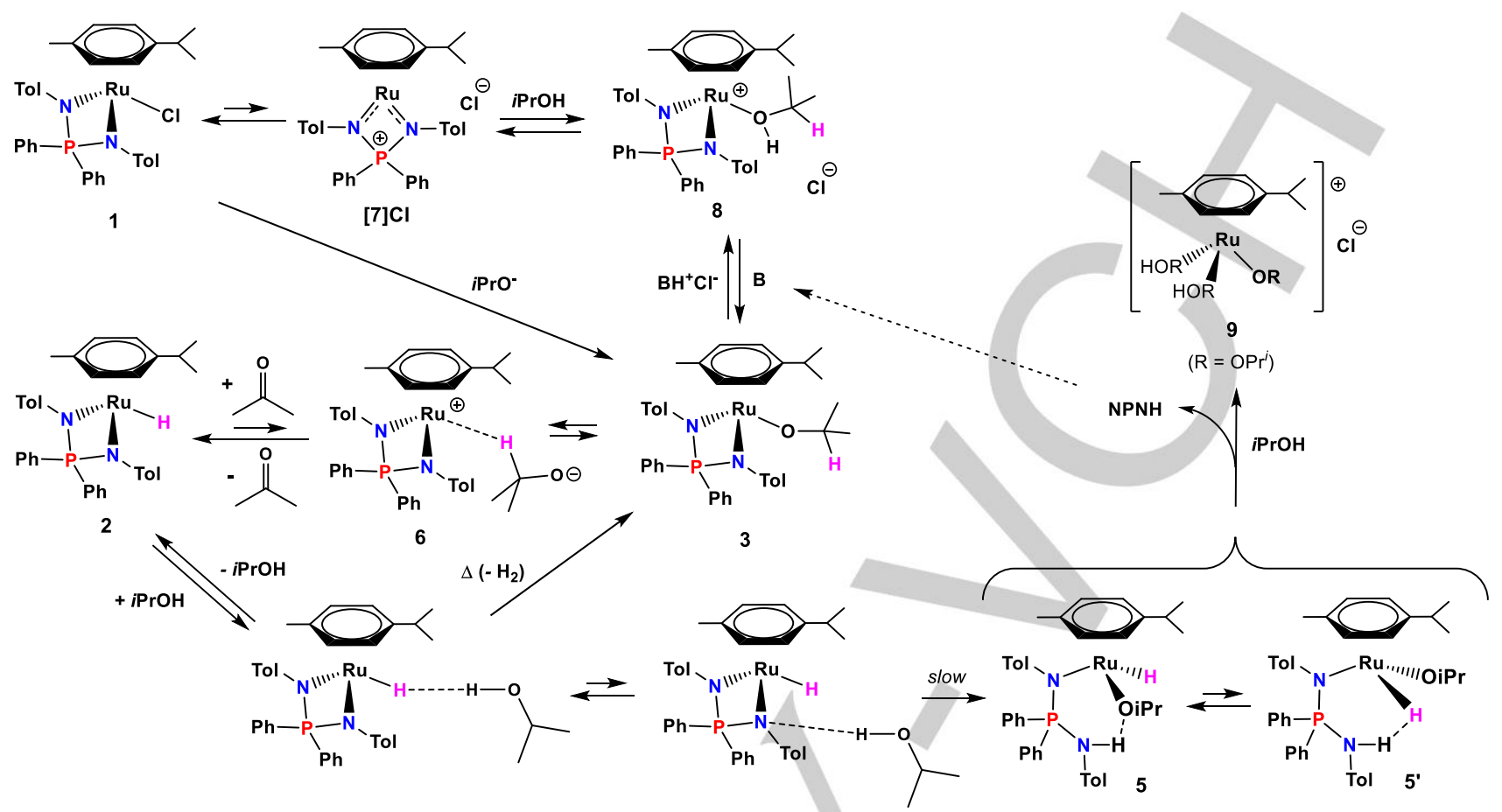

Scheme 2. Proposed mechanism for the generation of hydride 2 from 1, and related chemical processes.

degenerate proton transfer with NPNH, causing a broadening and a downfield shift for the ${ }^{31} \mathrm{P}$ NMR resonance with time (Figures S6 and S7). As stated above, the related $\left[\mathrm{Ph}_{2} \mathrm{P}(\mathrm{NH}-p-\mathrm{Tol})_{2}\right]^{+} \mathrm{Br}$ salt exhibits a ${ }^{31} \mathrm{P}$ NMR resonance at $\delta 28.0$ in $\mathrm{CDCl}_{3},{ }^{[10]}$ downfield shifted from that of NPNH. The observation of NPO may be rationalized through further degradation of $\mathrm{NPNH}$ and/or $\mathrm{NPNH}_{2}{ }^{+}$ by adventitious water with concomitant generation of $p$ - $\mathrm{TolNH}_{2}{ }^{[10]}$ A base $(B)$ is required to make the generation of isopropoxide 3 from 1 quantitative and rapid at room temperature. In this case, however, a direct associative exchange of $\mathrm{Cl}^{-}$with $\mathrm{O} i \mathrm{Pr}$ seems more likely. ${ }^{[9]}$ The $\beta-\mathrm{H}$ elimination in $\mathbf{3}$ to yield hydride $\mathbf{2}$ appears rather facile. However, compound $\mathbf{3}$ does not contain the open coordination site needed for a concerted intramolecular transformation to $\mathbf{2}$, while partial decoordination of the bidentate NPN and cymene ligands appears unlikely. We propose that this transformation follows the pathway of ionic dissociation followed by hydride transfer from the intermediate $\sigma$-complex $\mathbf{6}$. Additional evidence in support of this statement will be presented further below. This step thus appears competent to promote catalytic hydrogen transfer.

\section{(b) Isomerization of $\left[\left(\eta^{6}-\mathrm{Cym}\right) \mathrm{Ru}(\mathrm{NPN}) \mathrm{H}\right]$ to cyclohexadienyl system}

Complex 2 appears relatively stable at room temperature in neat iPrOH and also in aromatic hydrocarbons $\left(\mathrm{C}_{6} \mathrm{D}_{6}\right.$, toluene), provided $\mathrm{PrOH}$ is present. Standing in benzene or toluene solutions without a sufficient amount of protecting alcohol induced isomerization to $\mathbf{4}$ and $\mathbf{4}$ ', as already shown in Figure 1 and in
Figure S3. This conversion has further been investigated as follows. Generation of 2 from $\mathbf{1}$ and NaHMDS in neat $\mathrm{PrOH}$, followed by solvent removal and extensive drying, then extraction into ether and filtration to remove $\mathrm{NaCl}$, further drying and ${ }^{31} \mathrm{P}$ NMR analysis of the residue in $\mathrm{C}_{6} \mathrm{D}_{6}$, revealed greater relative intensities for the two resonances at $\delta 50.6$ and 51.1 of $\mathbf{4}$ and 4', relative to Figure 1a (see Figure 2a). When the same reaction was carried out in a toluene/iPrOH mixture and worked up in the same way, the corresponding spectrum showed $\mathbf{4}$ and $\mathbf{4}$ ' in even greater proportions (roughly $40 \%$ of the total, Figure $2 \mathrm{~b}$ ). Furthermore, generation of $\mathbf{2}$ by an alternative strategy ( $\mathbf{1}$ and $\mathrm{NaBHEt}_{3}$ in neat aromatic solvent, without any $\mathrm{PrOH}$ ), led again to a mixture of $\mathbf{2}$, 4 and 4' where the former was in minor proportion (Figure $2 \mathrm{c}$ ). It can be noted that the 4:4' ratio varies depending on conditions. Compound $\mathbf{4}$ is initially generated in greater relative proportions (kinetic product) but later equilibrates with the other isomer 4' (vide infra).

Single crystals of a disordered mixture of 4 and 4' were obtained directly from neat $\mathrm{PrOH}$, as shown by the X-ray structural determination. An ORTEP view of the molecule is shown in Figure 3. The asymmetric unit contains two complete and independent molecules with the same ring conformation and very similar metric parameters. The crystal used for the structural analysis was rather poor, but the structure was of sufficient quality to establish the geometry and the metric parameters of the $\mathrm{Ru}(\mathbf{N P N})$ part. In spite of several subsequent crystallization attempts, better crystals could not be obtained. The more problematic part of the structure is the cyclohexadienyl ring, which 
needed to be restrained at the anisotropic level during refinement in order to be well-behaved.

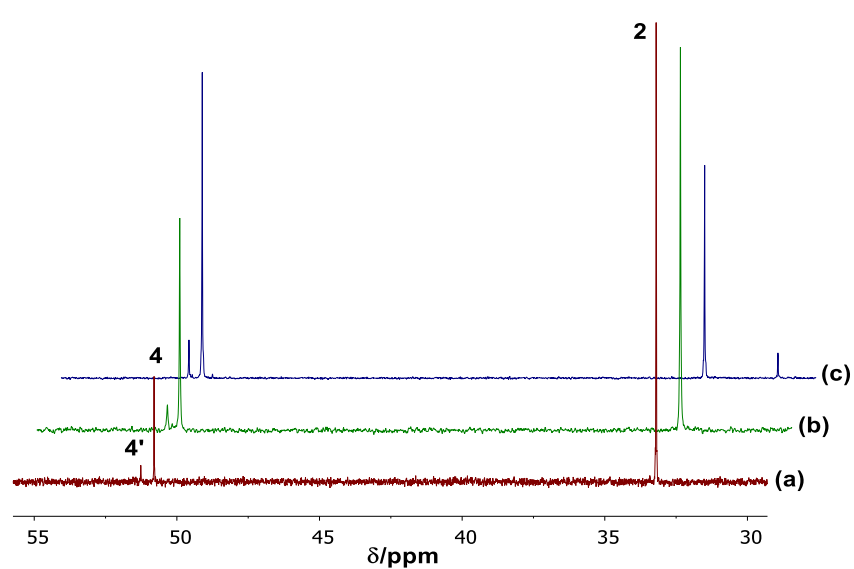

Figure 2. ${ }^{31} \mathrm{P}\left\{{ }^{1} \mathrm{H}\right\}$ spectra of samples of 2 obtained under various conditions. (a) From 1 and $\mathrm{NaHMDS}$ in neat $\mathrm{PrOH}$, followed by evaporation, extraction in $\mathrm{Et}_{2} \mathrm{O}$, filtration, evaporation and analysis in $\mathrm{C}_{6} \mathrm{D}_{6}$. (b) Same protocol as for spectrum (a), except for running the reaction in toluene in the presence of $\mathrm{PrOH}$. (c) From 1 and $\mathrm{NaBHEt}_{3}$ in $\mathrm{C}_{6} \mathrm{D}_{6}$

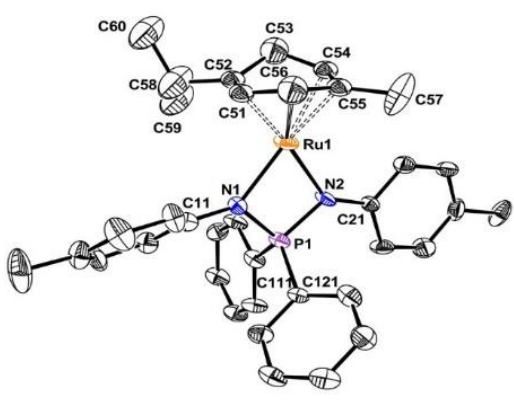

Figure 3. An ORTEP view of the disordered structure of $\mathbf{4}$ and 4'. Only one of the two independent molecule is shown. The ellipsoids are drawn at the $30 \%$ probability level and hydrogen atoms are not shown for clarity.

The analysis of the average positions of the ring $\mathrm{C}$ atoms indicates that two relative trans $\mathrm{C}$ atoms (C53 and C56 in the Ru1 molecule shown in Figure 3; C63 and C66 in the other molecule) are significantly displaced from the plane of the other four $\mathrm{C}$ atoms away from the $\mathrm{Ru}$ atom. This suggests disorder between two conformations that differ in the position of the $\mathrm{sp}^{3} \mathrm{C}$ atom (ortho to the CiPr or CMe group). Thus, the crystal appears to derive from the co-crystallization of the two isomers 4 and 4' (see Scheme 3 ). With the help of various NMR measurements, which are detailed in the supporting information (Figures S9-13), we assign 4 (i.e. the kinetic isomer) to the 1-Me-4-iPr cyclohexadienyl derivative and 4' to the 1-iPr-4-Me isomer. The observed deviation from the plane is greater for the atoms ortho to the $\mathrm{CiPr}$ group (C53 or the ring on Ru1, C63 for the ring on Ru2), suggesting that the crystal contains more of isomer 4' and less of
4. Unfortunately, the quality of the data set was not sufficient to refine the occupancies.
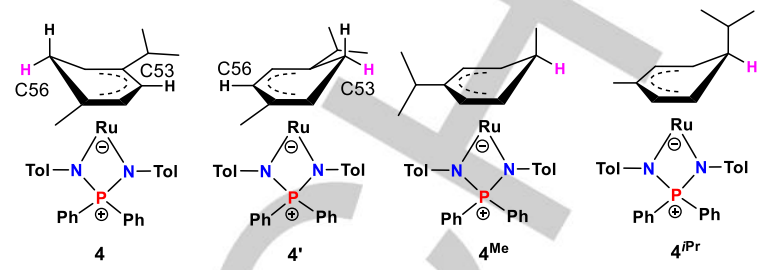

Scheme 3. Interpretation of the disorder observed in the X-ray structure of 4 and 4' and structures of the other two possible isomers $4^{\mathrm{Me}}$ and $4^{\mathrm{iPr}}$

The most relevant distances and angles are reported in Table 2 and the full list is available in the SI (Table S1). Because of disorder in the ring, the ring centroid was defined as the center of gravity of all six $\mathrm{C}$ atoms and the parameters related to this centroid should not be considered reliable. The coordination geometry is a typical 2-legged piano stool with the cyclohexadienyl ring approximately orthogonal to the $\mathrm{RuN}_{2} \mathrm{P}$ plane. This is isoelectronic with the cation [7] in the $[7] \mathrm{PF}_{6}$ salt, ${ }^{[9]}$ and indeed the structural features of the two compounds (compared in Table 2) are rather similar. Interestingly, whereas the Cambridge Crystallographic database contains $>2300$ X-ray structures of ( $\eta^{6}$ - $p$-cymene) complexes of transition metals, of which nearly all (>2100) are ruthenium complexes, this $4 / \mathbf{4}^{\prime}$ mixture is apparently the first reported structure, for any transition metal, with a cyclohexadienyl ligand derived from $p$-cymene. It is also only the second reported structure of a cyclohexadienyl derivative of $\mathrm{Ru}^{\text {II }}$ with a 16-electron configuration, the only other precedent being a compound where the cyclohexadienyl ligand is para-disubstituted by $\mathrm{CF}_{3}$ and by the $\beta$-diketiminate $\mathrm{CH}(\mathrm{CMe}=\mathrm{NAr})_{2}$ group $\left(\mathrm{Ar}=2,6-\mathrm{C}_{6} \mathrm{H}_{3}{ }^{i} \mathrm{Pr}_{2}\right)$, in which the bidentate anionic ligand is the same $\beta$-diketiminato (nacnac) ligand. ${ }^{[14]}$ An interesting point of comparison between these two structures is that both have a para-disubstituted cyclohexadienyl ligand but, whereas 4 and 4' have the two substituents in the 1 and 4 positions, namely the hydride has added to a $\mathrm{CH}$ position and not to a $\mathrm{CR}(\mathrm{R}=\mathrm{Me}$ or $\mathrm{Pr})$ position of the $p$-cymene ring, the previously published structure features these substituents in the 3 and 6 position, the sterically more encumbering $\beta$-diketiminate group occupying the sterically less congested 6 position $\left(\mathrm{sp}^{3} \mathrm{C}\right.$ atom) anti relative to $\mathrm{Ru}$. This difference may be related to the synthetic procedure, which consisted of external attack of the $\mathrm{PhCF}_{3}$ ligand by the $\beta$-diketiminate anion for the previously published compound, ${ }^{[14]}$ whereas $\mathbf{4}$ and 4' derive from an intramolecular migration of the hydride ligand from the $\mathrm{Ru}$ atom in 2 to the $o$ or $m \mathrm{C}$ atoms of the ring. The preferential formation of 4 and $4^{\prime}$ over the other two possible isomers $4^{\mathrm{Me}}$ and $4^{\mathrm{Pr}}$ (Scheme 3) may be kinetically favored by the greater partial positive charge of the sterically congested $o$ and $m \mathrm{C}$ atoms. This point has been further investigated by DFT calculations (see next section). 
Table 2. Relevant geometrical parameters and relative energies of the optimized structures of $\mathbf{2 B}, \mathbf{4 B}$ and TSB, with comparison with the geometries of related experimental structures.

\begin{tabular}{|c|c|c|c|c|c|c|c|c|c|c|}
\hline Parameter & 2B (M06L) & 2B (B97D) & $1^{[a]}$ & 4B (M06L) & 4B (B97D) & \multicolumn{2}{|c|}{$4 / 4^{\prime}[b]$} & {$[7]^{+} \mathrm{PF}_{6}^{-[\mathrm{a}]}$} & TSB (M06L) & TSB (B97D) \\
\hline & \multicolumn{10}{|c|}{ A. Distances $(\AA ̊)$} \\
\hline \multirow[t]{2}{*}{ Ru-N } & 2.167 & 2.164 & $2.145(2)$ & 2.164 & 2.121 & $2.061(12)$ & $2.060(12)$ & $2.031(2)$ & 2.173 & 2.132 \\
\hline & 2.174 & 2.158 & $2.126(2)$ & 2.135 & 2.124 & $2.090(13)$ & $2.119(14)$ & $2.017(3)$ & 2.175 & 2.152 \\
\hline Ru-(centroid) ${ }^{[c]}$ & 1.711 & 1.809 & & 1.647 & 1.677 & 1.743 & 1.689 & $1.659(1)$ & 1.687 & 1.714 \\
\hline \multicolumn{11}{|c|}{ B. Angles $\left({ }^{\circ}\right)$} \\
\hline N-Ru-N & 68.27 & 69.03 & $68.24(9)$ & 69.50 & 70.66 & $70.2(5)$ & $71.2(5)$ & $72.42(10)$ & 68.74 & 70.07 \\
\hline $\mathrm{N}-\mathrm{P}-\mathrm{N}$ & 96.99 & 96.32 & $96.73(13)$ & 97.50 & 96.67 & $95.8(7)$ & $97.7(7)$ & $94.59(13)$ & 98.05 & 97.12 \\
\hline \multirow[t]{2}{*}{$\Sigma N$} & 354.4 & 355.8 & $357.2(6)$ & 357.2 & 359.1 & 358.9 & 359.8 & $360.0(6)$ & 359.7 & 357.1 \\
\hline & 356.5 & 359.1 & $358.2(6)$ & 358.6 & 358.4 & 359.7 & 353.9 & $358.9(5)$ & 359.6 & 354.7 \\
\hline \multicolumn{11}{|c|}{ C. Energies (kcal/mol) } \\
\hline$\Delta \mathrm{E}_{\mathbb{P r O H}}$ & 0.0 & 0.0 & & -6.7 & -3.1 & & & & 34.4 & 36.7 \\
\hline$\Delta G_{\mathbb{P r O H}}$ & 0.0 & 0.0 & & -4.6 & 0.8 & & & & 33.0 & 34.9 \\
\hline
\end{tabular}

[a] From ref. [9]. [b] The values pertaining to the two crystallographically independent molecules are shown in different columns. [c] Centroid = center of gravity of the six arene $C$ atoms in the ( $\eta^{6}$-arene) and TS structures and in the experimental structure of 4 ; center of gravity of the five Ru-bonded C atoms in the DFToptimized ( $\eta^{5}$-cycloexadienyl) structures.

The structures of 4 and $\mathbf{4}^{\prime}$ in solution were confirmed by ${ }^{31} \mathrm{P}$ NMR, ${ }^{1} \mathrm{H}$ NMR, 2D COSY, ${ }^{13} \mathrm{C}, 2 \mathrm{D} \mathrm{H}-\mathrm{P}$ HMQC and 2D H-C HMQC spectra. Notably, only one set of signals for the NPN-moiety is found for each isomer in the ${ }^{1} \mathrm{H}$ NMR spectrum while the cyclohexadienyl ligand signals differ for $\mathbf{4}$ and 4' (see details in the $\mathrm{SI}$ ). In addition, ${ }^{31} \mathrm{P}$ EXSY NMR experiments carried out in $\mathrm{C}_{6} \mathrm{D}_{6}$ and toluene- $d_{8}$ in the temperature range $25-80^{\circ} \mathrm{C}$ did not reveal any cross peak between 2, $\mathbf{4}$ and 4', showing that these isomeric compounds interconvert slowly. The thermal treatment also resulted in the appearance of a third peak in the same region of the cyclohexadienyl isomer, at $\delta 51.6$, It appears reasonable to attribute this peak to one of the other possible isomers, $4^{\mathrm{Me}}$ or $4^{i \mathrm{Pr}}$ and the DFT calculations (see below) suggest that this is most likely $4^{\mathrm{IPr}}$. The interconversion between these isomers was further monitored by ${ }^{31} \mathrm{P}\left\{{ }^{1} \mathrm{H}\right\}$ NMR in toluene- $\mathrm{d}_{8}$ at $80^{\circ} \mathrm{C}$ (see Figure 4 ). The initial solution, prepared from 1 and NaHMDS in neat $\mathrm{PrOH}$ at room temperature as described above, shows a mixture of 2 (33\%), the two cyclohexadienyl isomers 4 and 4' at $\delta 50.6$ and 51.1 (42 and $21 \%$, the $\delta 50.6$ isomer being dominant), and a minor proportion of the third isomer at $\delta 51.6(4 \%)$, Figure $4 a$. Warming to $80^{\circ} \mathrm{C}$ for $1.5 \mathrm{~h}$ resulted in a change of the relative isomer proportion and to appearance of yet another peak at $\delta 53.0$, which could belong to the fourth isomer $4^{\mathrm{Me}}$. The intensity distribution changes to $\mathbf{2} / \mathbf{4}^{\prime} \mathbf{4}^{\prime} / \mathbf{4}^{\mathbf{P r}} / \mathbf{4}^{\mathrm{Me}}=\mathbf{1 6 / 3 5 / 3 5 / 1 2 / 2 \%}$ (Figure $4 b$ ). Hence, this thermal treatment resulted not only in the conversion of part of the hydride isomer $\mathbf{2}$ to the cyclohexadienyl structure but also to a redistribution of the cyclohexadienyl isomers among themselves, with an equilibration of the 4 and 4' proportion and a growth of the other two minor isomers $4^{\mathrm{IPr}}$ and $4^{\mathrm{Me}}$. Cooling back to room temperature and recording the NMR spectrum after $24 \mathrm{~h}$ did not significantly change the relative intensity of the resonances with respect to the high temperature spectrum $\left(\mathbf{2} / \mathbf{4} / \mathbf{4}^{\prime} / \mathbf{4}^{\mathrm{Pr}} / \mathbf{4}^{\mathrm{Me}}=18 / 34 / 34 / 11 / 3 \%\right.$; Figure $\left.4 \mathrm{c}\right)$. Therefore, the possible interconversion between the $\mathbf{2}$ and $\mathbf{4}$ isomers is a slow process.

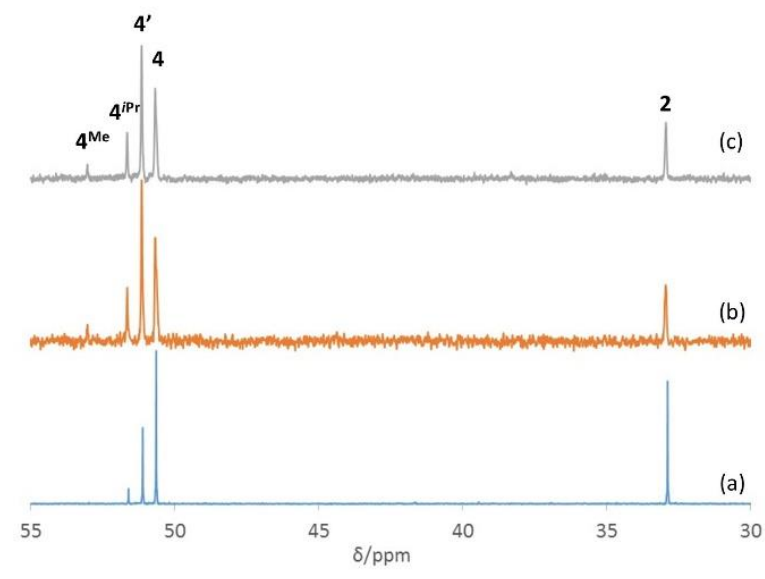

Figure 4. ${ }^{31} \mathrm{P} N M R$ spectra of the 2/4/4' mixture in $\mathrm{C}_{6} \mathrm{D}_{5} \mathrm{CD}_{3}$. The mixture was prepared from $1(15 \mathrm{mg})$ and $\mathrm{NaHMDS}(12 \mu \mathrm{L}, 1$ equiv) in neat $\mathrm{PrOH}(2 \mathrm{~mL})$, followed by drying and redissolution in the NMR solvent. (a) At $25^{\circ} \mathrm{C}$. (b) After $90 \mathrm{~min}$ at $80^{\circ} \mathrm{C}$. (c) At $25^{\circ} \mathrm{C}$, after standing for $24 \mathrm{~h}$ after spectrum (b). 
The stabilization of 2 relative to the cyclohexadienyl isomers by the presence of $\mathrm{PrOH}$ may be attributed to a stabilization by the "dihydrogen bond" (see Scheme 2), as proposed above on the basis of the hydride NMR resonance shift in the presence of alcohols. We have therefore explored the possible rearrangement of the isomeric hexadienyl complexes back to $\mathbf{2}$ in the presence of stronger proton donors than $\mathrm{PrOH}$, namely trifluoroethanol, $\mathrm{CF}_{3} \mathrm{CH}_{2} \mathrm{OH}$ (TFE) and hexafluoroisopropanol, $\left(\mathrm{CF}_{3}\right)_{2} \mathrm{CHOH}$ (HFIP). The addition of 10 equiv. of TFE to $\mathrm{a}_{6} \mathrm{D}_{6}$ solution of $\mathbf{2 , 4}$ and 4' ( ${ }^{31} \mathrm{P}$ NMR spectrum in Figure 5a), obtained as described above, induced a slight darkening from orange to orange-brown. The ${ }^{31} \mathrm{P}\left\{{ }^{1} \mathrm{H}\right\}$ NMR of this solution, recorded after $15 \mathrm{~min}$ at room temperature, is shown in Figure $5 \mathrm{~b}$. The $\left(\mathbf{4}^{+} \mathbf{4}^{\prime}\right) / \mathbf{2}$ intensity ratio does not decrease. It rather increases from $42: 58 \%$ to $66: 34 \%$, whereas the $4 / 4$ ' ratio changed slightly in favor of the minor resonance at $\delta 51.3$ (from $25: 75 \%$ to $36: 64 \%$ ). However, a new and broader resonance appears at $\delta 43.2$ (ca. 35\% of the total). This is the characteristic region of the $\left[\left(\eta^{6}-\mathrm{Cym}\right) \mathrm{Ru}(\mathbf{N P N}) \mathrm{X}\right]$ compounds $(\mathrm{X}=\mathrm{Cl}, \mathbf{1} ; \mathrm{H}, 2$; OPr, 3). We therefore assign this resonance to the alkoxide product $\left[\left(\eta^{6}-\mathrm{Cym}\right) \mathrm{Ru}(\mathbf{N P N})\left(\mathrm{OCH}_{2} \mathrm{CF}_{3}\right)\right]$ (3') (Scheme 4). Note that while the ${ }^{1} \mathrm{H}$ and ${ }^{31} \mathrm{P}$ resonances of residual 2 are slightly shifted as discussed above (Table 1), because of the formation of the "dihydrogen bonded complex" $\left[\left(\eta^{6}-\mathrm{Cym}\right) \mathrm{Ru}(\mathbf{N P N}) \mathrm{H} \cdots \mathrm{HOCH}_{2} \mathrm{CF}_{3}\right]$, those of residual 4 and 4' remain at exactly the same chemical shifts. The change of relative intensity for $\left(\mathbf{4}+\mathbf{4}^{\prime}\right)$ and $\mathbf{2}$ is therefore likely a consequence of the faster reaction of $\mathbf{2}$ with TFE to yield $\mathbf{3}^{\prime}$ than the isomerization of 4 and $\mathbf{4}$ ' to yield $\mathbf{2}$. Note also that this spectrum does not show any resonance above $60 \mathrm{ppm}$.

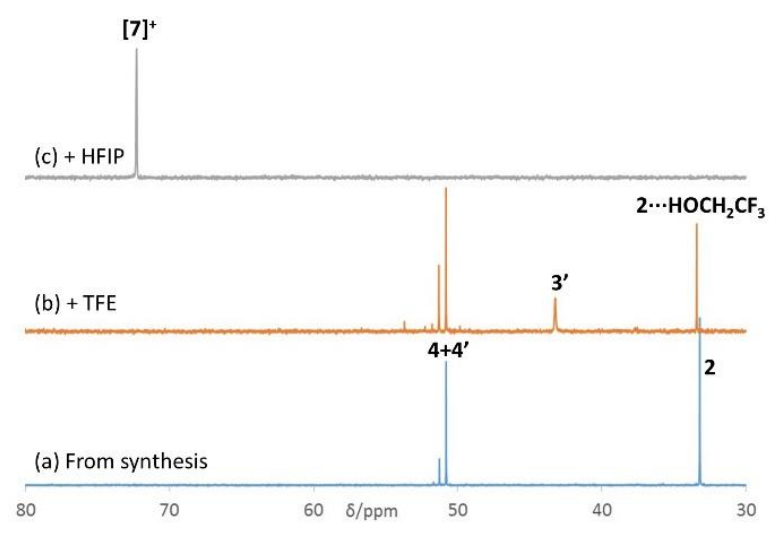

Figure 5. ${ }^{31} \mathrm{P}$ NMR spectra of the reaction between the 2/4/4' mixture and fluorinated alcohols in $\mathrm{C}_{6} \mathrm{D}_{6}$. (a) Conditions for the synthesis: $13 \mathrm{mg}(0.02 \mathrm{mmol})$ of 1 in $2 \mathrm{~mL}$ of $i \mathrm{PrOH}, 10 \mu \mathrm{L}$ of $2 \mathrm{M} \mathrm{NaHMDS}$ solution in THF (1 equiv), followed by drying and dissolution in the NMR solvent. (b) From (a), 15 min after adding TFE (14 $\mu \mathrm{L}, 0.2 \mathrm{mmol}, 10$ equiv) at room temperature. (c) From (a), recorded 15 min after adding HFIP $(20 \mu \mathrm{L}, 0.2 \mathrm{mmol}, 10$ equiv $)$ at room temperature.

Treatment of another $\mathbf{2} / \mathbf{4} / \mathbf{4}^{\prime}$ mixture, prepared in the same manner, in $\mathrm{C}_{6} \mathrm{D}_{6}$ with 10 equiv of HFIP under the same conditions, on the other hand, resulted in a completely different behavior. The color immediately changed from orange to dark blue and the ${ }^{31} \mathrm{P}\left\{{ }^{1} \mathrm{H}\right\}$ NMR spectrum indicated the total disappearance of $\mathbf{2}$ and
4/4' within 15 min with generation of a single product characterized by a resonance at $\delta 72.3$ (Figure $5 \mathrm{c}$ ). This clearly suggests the generation of the cationic complex $\left[\left(\eta^{6}-\right.\right.$ Cym)Ru(NPN)$]^{+}\left([7]^{+}\right)$by comparison with the resonance of the isolated $\mathrm{PF}_{6}$ - salt (a blue compound), which is reported as $\delta 72.3$ in $\mathrm{CDCl}_{3}{ }^{[9]}$ The corresponding ${ }^{1} \mathrm{H}$ NMR spectrum (Figure $\mathrm{S} 14$ ) confirms this assignment. Furthermore, the generation of molecular hydrogen, resulting from the protonation of the hydride ligand by HFIP (Scheme 4), is confirmed by the observation of a signal at $\delta 4.48$ in the ${ }^{1} \mathrm{H}$ NMR. Note that 3 ' and $[7]\left[\mathrm{OCH}\left(\mathrm{CF}_{3}\right)_{2}\right]$ have the same stoichiometry. The difference between these two reactions is notable in the kinetics, thermodynamics and nature of the product (immediate and quantitative for HFIP to yield [7] ${ }^{+}$, slow and partial for TFE to yield $\mathbf{3}^{\text {') }}$ as a result of the different proton donor strength of the two alcohols and of the lower coordinating power of the hexafluoroisopropoxide anion. However, both TFE and HFIP are sufficiently acidic to transfer their proton to the hydride ligand of complex 2 . We recall here that even the weaker acid $\mathrm{PrOH}$ has given evidence in favor of the transformation of 2 to the corresponding alkoxide 3 (Figure S5), although only partially and under forcing conditions. The rapid disappearance of 4 and '4' in the presence of HFIP suggests that this alcohol also has either a strong effect on the rate of the $\mathbf{2} / \mathbf{4}$ interconversion, or that it is capable to directly abstract a hydride from the cyclohexadienyl ring.

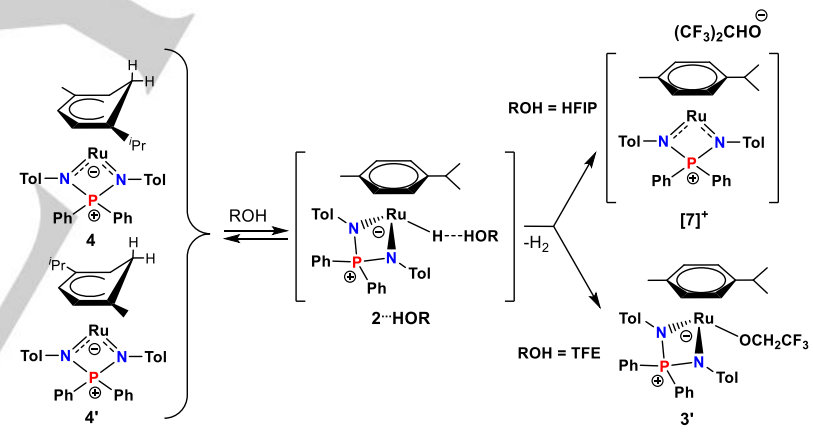

Scheme 4. Reaction of 2/4/4' with fluorinated alcohols

The above results have an interesting implication: the isopropoxide compound $\mathbf{3}$ is a neutral 18-electron complex that does not spontaneously ionize to the cation $\left[\left(\eta^{6}-\mathrm{Cym}\right) \mathrm{Ru}(\mathbf{N P N})\right]^{+}$ plus isopropoxide, therefore the opposite process is spontaneous (equation 1); compound 3 irreversibly releases acetone to generate compound 2 (equation 2); finally, the latter reacts with HFIP to yield the $\left[\left(\eta^{6}-\mathrm{Cym}\right) \mathrm{Ru}(\mathbf{N P N})\right]^{+}$cation and hexafluoroisopropoxide (equation 3). Summing up the three equations yields equation 4, where HFIP delivers the proton to the methynic "hydride" of isopropoxide to produce $\mathrm{H}_{2}$ and acetone, rather than to the more basic oxygen atom to yield isopropanol. This is a slightly less thermodynamically favorable process (by ca. 3.3 $\mathrm{kcal} / \mathrm{mol}$, corresponding to the $\Delta \mathrm{G}$ of the isopropanol dehydrogenation). ${ }^{[15]}$ Nevertheless, this thermodynamic cycle consideration proves that it is a downhill process. 


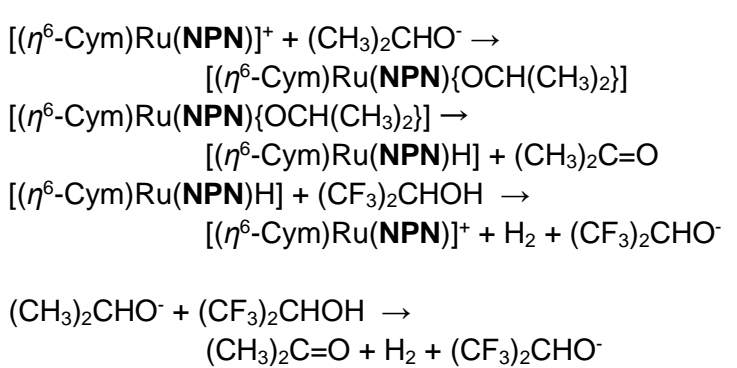

(c) DFT calculations on the hydride complex 2 and cyclohexadienyl isomers

The DFT calculations were carried out with two specific objectives in mind: i) validate the high activation barrier for the $2 / 4$ isomerizations; ii) validate the greater stability and kinetic accessibility of the $\mathbf{4}^{\text {and }} \mathbf{4}^{\prime}$ isomers relative to $4^{\mathrm{Pr}}$ and $\mathbf{4}^{\mathrm{Me}}$. For the first purpose, the calculations were carried out on a simplified model where $p$-cymene was replaced with a non-substituted benzene ring. The NPN ligand, on the other hand, was kept essentially unchanged, replacing only the tolyl $p$-Me groups, which are both electronically and sterically almost inconsequential, with $\mathrm{H}$ atoms. The Cartesian coordinates and energies of all optimized geometries are collected in Table S3.

Initial exploration of the relative stability of the $\left[\left(\eta^{6}-\right.\right.$ $\left.\left.\mathrm{C}_{6} \mathrm{H}_{6}\right) \mathrm{Ru}\left(\mathrm{PhNPPh}{ }_{2} \mathrm{NPh}\right) \mathrm{H}\right] \quad\left(2 \mathrm{~B} ; \mathrm{B}\right.$ for benzene) and $\left[\left(\mathrm{n}^{5}-\right.\right.$ $\left.\left.\mathrm{C}_{6} \mathrm{H}_{7}\right) \mathrm{Ru}\left(\mathrm{PhNPPh}_{2} \mathrm{NPh}\right)\right](\mathbf{4 B})$ isomers were carried out with two standard functionals (M06L and B97D), all geometries being reoptimized with each functional. The calculations with the former functional were corrected for long-range dispersion interactions by Grimme's GD3 method, ${ }^{[16]}$ whereas the B97D functional already considers dispersive forces. The calculations with both functionals were further corrected for the thermal parameters at $298.15 \mathrm{~K}$ and for solvation effects in isopropanol using a polarizable continuum model. The overall results were quite similar. Both show a slight preference for the cyclohexadienyl structure in terms of electronic energy $\left(\Delta E_{\mathrm{iPrOH}}\right)$, a bit greater with the M06L-D3 approach (see Table 2). This remains the preferred isomer also in terms of $\Delta G_{\mathrm{PrOH}}$ at the M06L-D3 level, whereas the hydride becomes slightly preferred at the B97D level. The activation barrier for the 2/4 interconversion, involving $\mathrm{H}$ atom transfer between the $\mathrm{Ru}$ atom and a ring $\mathrm{C}$ atom, was also evaluated with both functionals, giving again similar geometries and energies for the transition state TSB, which were rather high relative to the starting and ending isomers $\mathbf{2 B}$ and $\mathbf{4 B}$. The Mulliken charge on the $\mathrm{H}$ atom involved in the isomerization process goes from slightly negative in $\mathbf{2 B}(-0.094, \mathrm{M} 06 \mathrm{~L} ;-0.111$, B97D) to slightly positive in TSB $(0.050, \mathrm{M06L} ; 0.077, \mathrm{~B} 97 \mathrm{D})$ and then more positive in 4B (0.110, M06L; 0.134 , B97D). The transition state is at high energy presumably because of the need to extensively distort the coordination geometry and because there is more extensive bond breaking than bond forming (e.g. the $\mathrm{Ru} \cdots \mathrm{H}$ and $\mathrm{H} \cdots \mathrm{C}$ bonds in TSB are 1.836 and $1.394 \AA$ at the M06 level or 1.842 and $1.426 \AA$ at the B97D level; vs. 1.601 or 1.575 $\AA$ for $\mathrm{Ru}-\mathrm{H}$ in $2 \mathrm{~B}$ and 1.094 or $1.098 \AA$ for $\mathrm{C}-\mathrm{H}$ in $4 \mathrm{~B})$. This result justifies the experimental observation of a very slow interconversion between $\mathbf{2}$ and the hexadienyl isomers, and between the hexadienyl isomers among themselves. The isomerization of one hexadienyl isomer into another, e.g. from 4 to $4^{\prime}$ or to $4^{\mathrm{IPr}}$, would presumably have to transit through the hydride isomer 2.

In terms of optimized geometries, the parameter of greatest interest is the pyramidalization of the $\mathrm{N}$ atoms in the NPN ligand, as evaluated by the sum of the three bond angles, $\mathrm{C}(\mathrm{Ar})-\mathrm{N}-\mathrm{Ru}$, $\mathrm{Ru}-\mathrm{N}-\mathrm{P}$ and $\mathrm{P}-\mathrm{N}-\mathrm{N}(\mathrm{Ar})$ (indicated as $\Sigma \mathrm{N}$ in Table 2). This provides information on the delocalization of the $\mathrm{N}$ lone pair onto the aryl substituent and on the Ru atom (for the electronically unsaturated structure of $\left.\mathbf{4} / \mathbf{4}^{\prime}\right)$. The calculations indicate that $\Sigma \mathrm{N}$ is close to $360^{\circ}$ (planarity) not only for the cyclohexadienyl structure $4 \mathrm{~B}$, but also for the 18-electron complex $\mathbf{2 B}$, suggesting efficient delocalization of the $\mathrm{N}$ lone pair onto the phenyl substituent. This corresponds to the experimental evidence, not only for the 16-electron complexes 4/4' and [5] ${ }^{+} \mathrm{PF}_{6}$, but also for the 18-electron complex 1 (a structure for the hydride derivative could not be obtained, thus we compare with the isoelectronic chloride complex). On the other hand, related compounds with alkyl substituents on the $\mathrm{N}$ atom of the NPN ligand shown significant pyramidalization in 18-electron structures (e.g. $\Sigma \mathrm{N}=344.4(8)$ and $357.6(8)^{\circ}$ in $\left[\left(n^{6}-\right.\right.$ $\left.\mathrm{C}_{6} \mathrm{Me}_{6}\right) \mathrm{RuCl}\left(\mathrm{MeNPPh} \mathrm{NMe}_{2}\right]^{[8]}$

In terms of the second objective, we have chosen to drastically simplify the NPN ligand for computational efficiency by replacing all $\mathrm{Ph}$ and $\mathrm{Tol}$ substituents with $\mathrm{H}$ atoms, since the nature of the NPN substituents should not affect to a great extent the relative stability of the different cyclohexadienyl isomers. The ring, on the other hand, was introduced in the calculations without any simplification. Because the four different isomers contain exactly the same number and type of bonds, we have only used one functional to evaluate their relative energy, selecting B97D. The results (see Figure 6) show that, in agreement with the experimental evidence, isomers $\mathbf{4} \mathbf{H}$ and $\mathbf{4} \mathbf{H}$ ' $(\mathbf{H}$ for hydrogen on the NPN ligand) are more stable that the other two isomers. Their relative energies are quite close, but significantly lower than those of $\mathbf{4} \mathrm{H}^{\mathrm{Pr}}$ and $\mathbf{4} \mathrm{H}^{\mathrm{Me}}$. This relative energy ordering suggests the assignment of the observed resonances in the 50-53 ppm region of the ${ }^{31} \mathrm{P}$ NMR spectrum as proposed in Figure $4: \delta 53.0$ for $4^{\mathrm{Me}}$, $\delta 51.6$ for $4^{\mathrm{Pr}}$. Concerning the two resonances at $\delta 51.1$ and 50.6 , the relative $1: 1$ intensity after extensive warming in toluene at $80^{\circ} \mathrm{C}$ (vide supra) suggests that they should have the same energy, whereas the calculations show a slight preference for $\mathbf{4} \mathbf{H}^{\prime}$. The small discrepancy, which is well within the accepted margin of computational error, may in part be related to the simplification of the NPN ligand. The preferred generation at room temperature of the isomer characterized by the $\delta 50.6$ resonance indicates kinetic control for the $\mathrm{H}$ atom transfer from the $\mathrm{Ru}$ atom to the ring $\mathrm{C}$ atom. We did not calculated the relative barriers for the $\mathrm{H}$ atom transfer to all four different types of $\mathrm{C}$ atom in the $p$-cymene ligand. Steric arguments, however, are consistent with the faster formation of $\mathbf{4}$ since the $\mathrm{H}$ ligand migrates to the $\mathrm{C}$ atom ortho to the less hindered CMe group.

In terms of optimized geometries, it is of interest to observe that the $\mathrm{N}$ atoms are significantly pyramidalyzed the $\Sigma N$ parameter being in the 325.4-343.1 $1^{\circ}$ range (see Table 3 ). This difference relative to the $\mathrm{PhNPPh}_{2} \mathrm{NPh}$ models discussed above (2B, 4B and TSB) is related to the inability of the $\mathrm{N}$ atoms to 
delocalize their lone pair onto the $\mathrm{H}$ substituent, in spite of the possible partial delocalization to the Ru center in the 16-electron systems.

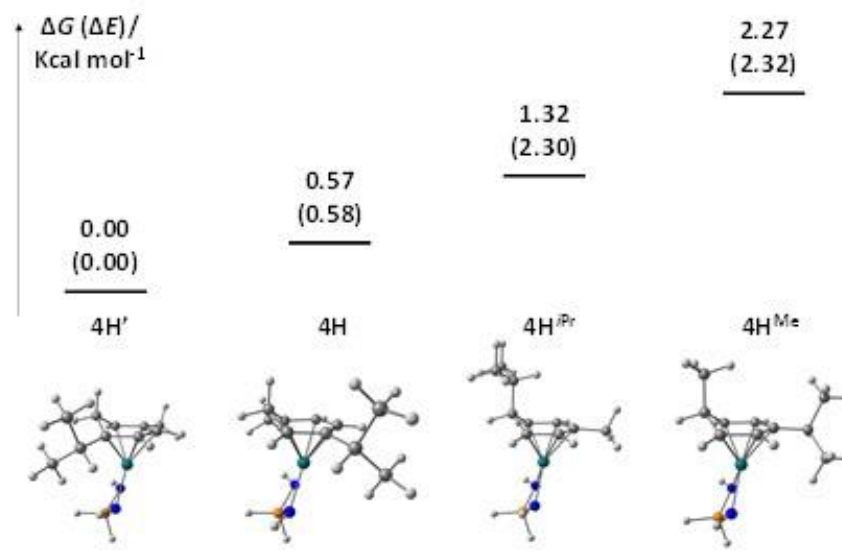

Figure 6. Relative gas phase energies ( $\Delta G$ and $\Delta E$ in parentheses, in kcal mol $\left.{ }^{1}\right)$ and views of the optimized geometries for the model compounds of the four different isomers $4,4^{\prime}, 4^{\mathrm{Me}}$ and $4^{\mathrm{iPr}}$. yield of product in $24 \mathrm{~h}$. It is relevant to point out that many other chloride precatalysts are not active unless transformed to the active hydride species by treatment with a strong base in the alcohol solvent. ${ }^{[17]}$ The activity in this case may be attributed to the spontaneous generation of the hydride complex 2 in the system, even in the absence of base, as shown above in part a (Scheme 2).

Table 4. Results of the catalytic transfer hydrogenation of acetophenone. ${ }^{[a]}$

\begin{tabular}{|c|c|c|c|c|c|}
\hline Entry & Precatalyst & Solvent ${ }^{[b]}$ & $\mathrm{B} / \mathrm{Ru}[\mathrm{c}]$ & $\mathrm{T}\left({ }^{\circ} \mathrm{C}\right)$ & $\mathrm{K}_{\text {obs }}\left(\mathrm{h}^{-1}\right)^{[\mathrm{d}]}$ \\
\hline
\end{tabular}

\begin{tabular}{llllll}
\hline 1 & {$\left[\left(\eta^{6}-\mathrm{Cym}\right) \mathrm{RuCl}_{2}\right]_{2}$} & A & - & 40 & n.d. \\
2 & $\mathbf{1}$ & A & - & 60 & $0.076 \pm 0.002$ \\
3 & {$[7] \mathrm{BF}_{4}$} & A & - & 60 & n.d. \\
4 & 1 & A & - & 60 & $<0.03$
\end{tabular}

\begin{tabular}{llllll}
6 & 1 & A & - & 80 & $0.606 \pm 0.011$ \\
7 & {$\left[\left(\eta^{6}-\mathrm{Cym}\right) \mathrm{RuCl}_{2}\right]_{2}$} & $\mathrm{~A}$ & 2 & 40 & $0.034 \pm 0.002$ \\
8 & $\mathbf{1}$ & $\mathrm{A}$ & 1.5 & 40 & $0.336 \pm 0.002$ \\
9 & $\mathbf{1}$ & $\mathrm{A}$ & 1.5 & 60 & $0.81 \pm 0.02$ \\
10 & $\mathbf{1}$ & $\mathrm{C}$ & 2 & 60 & $0.74 \pm 0.06$ \\
11 & $\mathbf{1}$ & $\mathrm{A}$ & 10 & 80 & $1.42 \pm 0.05$ \\
12 & $\mathbf{1}$ & $\mathrm{A}$ & 1 & 25 & $0.095 \pm 0.001$ \\
13 & {$[7] \mathrm{PF}_{6}$} & A & 1.5 & 25 & $0.1082 \pm 0.0008$ \\
\hline
\end{tabular}

Table 3. Relevant geometrical parameters of the optimized structures of $\mathbf{4 H}$,

\begin{tabular}{|c|c|c|c|c|}
\hline parameter & $4 \mathrm{H}$ & $4 \mathrm{H}^{\prime}$ & $4 \mathrm{H}^{\mathrm{Me}}$ & $4 \mathrm{H}^{\mathrm{IPr}}$ \\
\hline \multicolumn{5}{|l|}{ Distances $(\AA)$} \\
\hline \multirow{2}{*}{ Ru-N } & 2.218 & 2.215 & 2.210 & 2.1 \\
\hline & 2.212 & 2.211 & 2.204 & 2.135 \\
\hline Ru-(centroid) ${ }^{[a]}$ & 1.747 & 1.759 & 1.757 & \\
\hline \multicolumn{5}{|l|}{ Angles $\left({ }^{\circ}\right)$} \\
\hline N-Ru-N & 69.38 & 69.18 & 69.57 & 70.95 \\
\hline N-P-N & 99.92 & 99.50 & 99.71 & 99.14 \\
\hline \multirow{2}{*}{$\Sigma N$} & 319.0 & 322.7 & 320.5 & 329.9 \\
\hline & 319.1 & 317.9 & 319.1 & 339.5 \\
\hline (centroid)-Ru-P [a] & 159.94 & 160.99 & 159.06 & 165.15 \\
\hline
\end{tabular}

[a] Centroid = center of gravity of the five Ru-bonded C atoms.

\section{(d) Transfer hydrogenation catalysis}

Compounds 1 and $[7]^{+}$(as the $\mathrm{PF}_{6}$ or $\mathrm{BF}_{4}$ salts) were tested as catalysts for the transfer hydrogenation of acetophenone by isopropanol, in comparison with the commercial precursor $\left[\left(\eta^{6}-\right.\right.$ Cym) $\left.\mathrm{RuCl}_{2}\right]_{2}$. The results obtained from the various experiments are listed in Table 4 and all data are collected in Table S2. Complex $\left[\left(\eta^{6}-\mathrm{Cym}\right) \mathrm{RuCl}_{2}\right]_{2}$ does not catalyze the reaction in the absence of base (entry 1). Using compound 1 in the absence of base resulted in catalytic activity at $60^{\circ} \mathrm{C}$ (entry 2 ) with a $62.4 \%$

[a] Standard conditions : $233 \mu \mathrm{L}$ of acetophenone (2 mmol) and $226 \mu \mathrm{L}$ of internal standard (dodecane) in $5 \mathrm{~mL}$ of solvent $\left([\mathrm{PhCOMe}]=3.66 \cdot 10^{-1} \mathrm{M}\right)$, $0.02 \mathrm{mmol}$ of Ru catalyst (1\% catalyst loading); unless otherwise stated, the catalytic mixture was conditioned at the reaction temperature for $15 \mathrm{~min}$ before the substrate addition. [b] A: $\mathbb{P r O H}(5 \mathrm{~mL}) ; \mathrm{B}: \mathbb{P r O H}(2.5 \mathrm{~mL})+\mathrm{C}_{6} \mathrm{H}_{6}$ (2.5 mL); C: $\mathrm{PrOH}(2.5 \mathrm{~mL})+\mathrm{C}_{6} \mathrm{H}_{5} \mathrm{CH}_{3}(2.5 \mathrm{~mL})$. [c] Molar ratio NaHMDS/Ru. [d] From the slope of the first order kinetics plot in the linear region (n.d. $=$ not determined). [e] Conditioned at $60^{\circ} \mathrm{C}$ for $2 \mathrm{~h}$ before the substrate addition.

The kinetic analysis of entry 2 shows a relatively good first order behavior during the first $6 \mathrm{~h}$ (see Figure 7), but catalyst decomposition occurs at longer times as suggested by the observed deviation from linearity for the first-order plot after $24 \mathrm{~h}$ (Figure S15). This is in line with the observed thermal degradation of 2 (part a), even though increasing amounts of $\mathrm{PrOH}$ were shown to have a protecting effect. A run carried out under the same conditions using [7]BF 4 in place of 1 showed no significant activity (entry 3 ). In order to probe the catalyst stability, an additional run was carried out under the same conditions as run 2 , except that the catalyst solution was kept at $60^{\circ} \mathrm{C}$ for 2 hours, instead of only $15 \mathrm{~min}$, before introducing the substrate (entry 4). The dramatic reduction of activity (only $15.7 \%$ conversion after 6 h, vs. $36.2 \%$ for entry 2) confirms that the catalyst is degraded 
under these conditions. Note, however, that the linearity of the first order plot of entry 2 in the first $6 \mathrm{~h}$ (Figure S15) suggests a slower degradation in the presence of substrate. In other words, the substrate also seems to exert, like the isopropanol solvent, a slight protective role against catalyst decomposition. Since the stoichiometric studies presented in part a have indicated a solvent effect on the stability of the hydride complex 2, we have also carried out an additional test under the same experimental conditions, except for replacing $\mathrm{PrOH}$ with a 1:1 mixture of $\mathrm{PrOH}$ and benzene (entry 5). The result of this experiment are essentially identical to those of entry 2 , including the activity reduction after the first 6 hours (Figure S15). This suggests that $50 \%$ of $\mathrm{PrOH}$ in the solvent mixture is sufficient to provide a roughly equivalent protecting effect to the active catalyst. A final experiment in the absence of base was carried out at $80^{\circ} \mathrm{C}$ (entry 6 ). As expected, the activity was greater, the product yield reaching to $95 \%$ after $5 \mathrm{~h}$. At $80^{\circ} \mathrm{C}$, like at $60^{\circ} \mathrm{C}$, the catalyst activity is maintained sufficiently to provide a linear first-order kinetic plot during the first $5 \mathrm{~h}$ (see Figure 7).

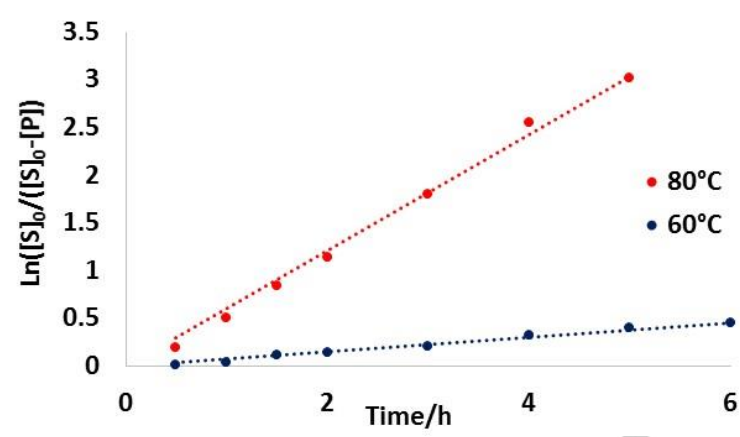

Figure 7. First order kinetics analyses of the acetophenone transfer hydrogenation in isopropanol catalyzed by 1 in the absence of base. Blue line $\left(60^{\circ} \mathrm{C}\right)$, entry 2 ; red line $\left(80^{\circ} \mathrm{C}\right)$, entry 6 (Table 4$)$.

The remainder of the catalytic tests were carried out in the presence of at least one equivalent of NaHMDS, which quantitatively transforms $\mathbf{1}$ to the hydride complex $\mathbf{2}$ (see part a). A control experiment with the precursor complex $\left[\left(\eta^{6}-\mathrm{Cym}\right) \mathrm{RuCl}_{2}\right]_{2}$ (entry 7 ) shows low but non-negligible activity, with a $57.4 \%$ yield of 2-phenylethanol in $24 \mathrm{~h}$ at $40^{\circ} \mathrm{C}$ and a TOF of $3.44 \mathrm{~h}^{-1}$. Thus, the presence of base is essential for this precatalyst. The related $\mathrm{C}_{6} \mathrm{Me}_{6}$ and $\mathrm{C}_{6} \mathrm{H}_{3} \mathrm{Me}_{3}$ precatalysts ${ }^{[18]}$ were shown to generate the corresponding dinuclear hydride complexes [(Arene) $\mathrm{Ru}(\mu-\mathrm{H})_{2}(\mu$ $\mathrm{Cl}) \mathrm{Ru}($ Arene $)]^{+} \mathrm{Cl}^{-}$under the same conditions, as a result of $\beta-\mathrm{H}$ elimination from the corresponding $\mu$-isopropoxide intermediate. ${ }^{[13]}$ At the same temperature, use of compound 1 leads to a tenfold increase of $k_{\text {obs }}$ (entry 8 ), demonstrating the positive effect of the NPN ligand. However, thermal degradation was observed after the initial linear region of the first order plot (see Figure $\mathrm{S} 16 \mathrm{a}$ ), because conversion reaches only $93.8 \%$ after $24 \mathrm{~h}$, whereas extrapolation of the initial activity should afford essentially quantitative conversion (>99\%) in less than $20 \mathrm{~h}$. Increasing the temperature to $60^{\circ} \mathrm{C}$ results in a $k_{\text {obs }}$ increase to
$0.81 \mathrm{~h}^{-1}$ (entry 9) and shows a faster onset of the catalyst decomposition because the linearity of the $1^{\text {st }}$ order plot is lost after the first $2 \mathrm{~h}$ (Figure S16b). Comparison of entries 2 and 9 in Table 4 shows that the base increases the catalytic activity by a factor of ca. 10, which we believe is related to the quantitative generation of catalytically active 2. At this temperature, an additional experiment was also carried out in a 50:50 $\mathrm{PrOH}$ toluene solvent mixture (entry 10), giving a similar result relative to the neat $\mathrm{PrOH}$ solvent (Figure S16c). This result is similar to that of the above discussed base-free system, with the catalyst degradation being perhaps a bit faster in this case (onset before $2 \mathrm{~h})$. Two additional experiments were carried out at higher $\left(80^{\circ} \mathrm{C}\right.$, entry 11$)$ and lower $\left(25^{\circ} \mathrm{C}\right.$, entry 12$)$ temperatures. At the higher temperature, essentially full conversion was attained in $4 \mathrm{~h}$ and the catalyst degradation phenomenon is evident once again after ca. $2 \mathrm{~h}$ (Figure S16d), whereas the slower catalyst decomposition at $25^{\circ} \mathrm{C}$ gave a linear $1^{\text {st }}$ order behavior up to 8 hours, but the slower conversion lead to ultimate decomposition with stagnation of the substrate conversion at ca. $82 \%$ after $30 \mathrm{~h}$ (Figure S16e). The $1^{\text {st }}$ order plots at the four different temperatures in the initial linear region are collected in Figure 8a.
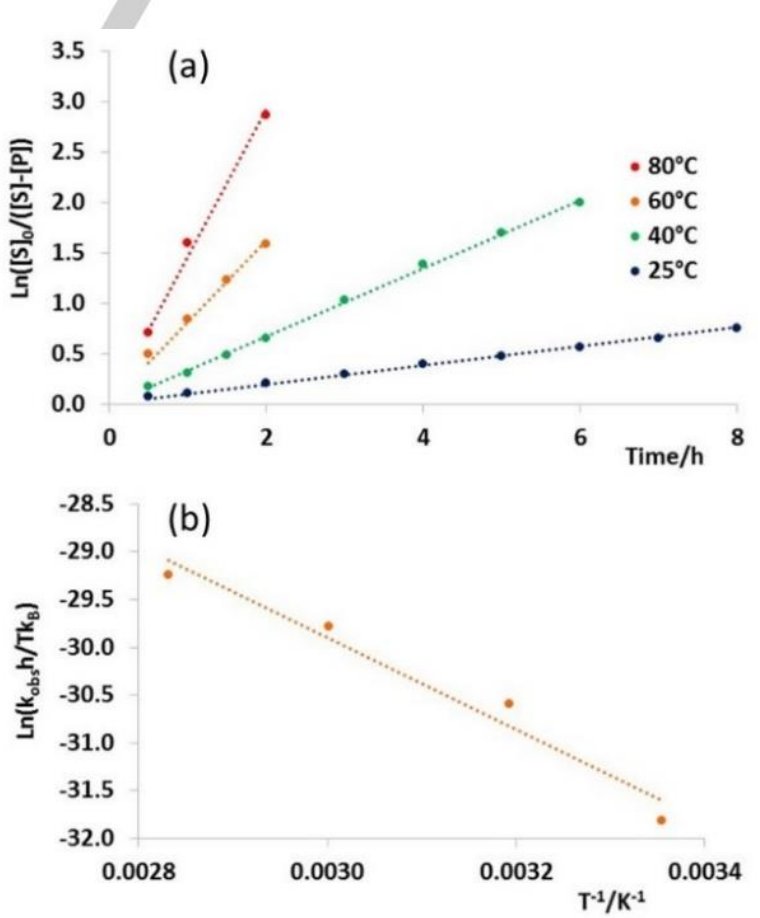

Figure 8. (a) First order kinetics analyses of the acetophenone transfer hydrogenation in isopropanol catalyzed by 1 in the presence of base at different temperatures: blue line, run 12; green line, run 8; orange line, run 9; red line run 11 (Table 4). (b) Eyring analysis of the observed $1^{\text {st }}$ order rate constants.

An Eyring analysis of the resulting $1^{\text {st }}$ order rate constants, shown in Figure $8 \mathrm{~b}$, yields the activation parameters $\Delta H^{*}=$ $9.6 \pm 1.3 \mathrm{kcal} \mathrm{mol}^{-1}$ (enthalpy span of the catalytic cycle) and $\Delta S^{\ddagger}$ $=-31 \pm 4 \mathrm{cal} \mathrm{mol}^{-1} \mathrm{~K}^{-1}$. The large negative activation entropy suggests a high level of ordering upon going from the resting state 
to the rate-determining transition state. A final experiment (entry 13) consisted in testing the [7]PF 6 salt as precatalyst at $25^{\circ} \mathrm{C}$, under the same conditions used for precatalyst 1 in run 12 . It must be recalled that, in the absence of base, this compound shows essentially no catalytic activity (entry 3 ). However, in the presence of NaHMDS it gives rise to the same activity as precatalyst 1 (cf. entries 12 and 13 in Table 4), suggesting that the base transforms both compounds into the same catalytically active species. Quite clearly, the collective catalytic experiments, in combination with the stoichiometric studies of part $(a)$, demonstrate the direct implication of the hydride complex 2 in the catalytic cycle.
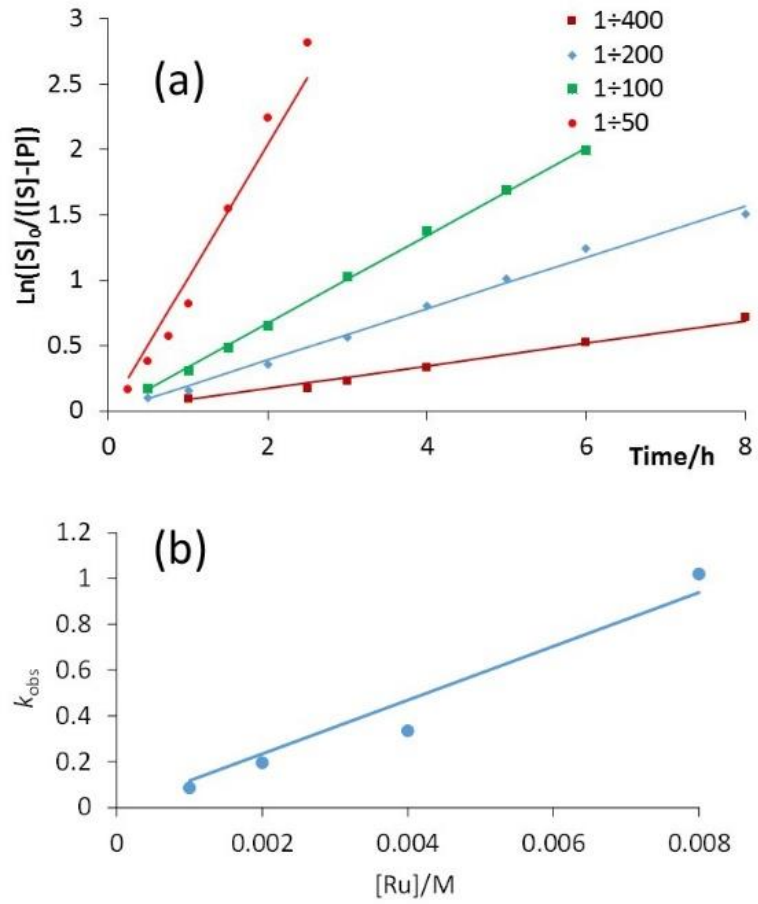

Figure 9. (a) First order kinetics analyses of the acetophenone transfer hydrogenation in isopropanol catalyzed by $\mathbf{1}$ at different concentrations (data from Table S2). (b) Plot of the observed $1^{\text {st }}$ order rate constant versus the catalyst concentration.

Additional catalytic runs were also carried out at $40^{\circ} \mathrm{C}$ and at different catalyst concentrations. The conversion data are collected in Table S2 and the full first order plots are in Figure S17. Once again, catalyst decomposition was evident from the $1^{\text {st }}$ order kinetic plots, but a sufficient number of points could be collected within the catalyst stability period (see Figure 9a) to derive observed rate constants, which are collected in Table 5. From the $k_{\text {obs }}$ vs. $[\mathrm{Ru}]$ plot (Figure 9b), a second order rate constant $k=$ $117 \pm 10 \mathrm{M}^{-1} \mathrm{~h}^{-1}$ was obtained.
Table 5. Catalyzed transfer hydrogenation of acetophenone with $1 / \mathrm{NaHMDS}$ at different catalyst concentration. ${ }^{[a]}$

\begin{tabular}{llll}
\hline Entry & {$[\mathrm{Ru}](\mathrm{M})$} & Ru:substrate & $\mathrm{K}_{\mathrm{obs}}\left(\mathrm{h}^{-1}\right)^{[\mathrm{b}]}$ \\
\hline 14 & 0.001 & 0.0025 & $0.086 \pm 0.002$ \\
15 & 0.002 & 0.005 & $0.196 \pm 0.004$ \\
16 & 0.004 & 0.01 & $0.336 \pm 0.003$ \\
17 & 0.008 & 0.02 & $1.02 \pm 0.09$ \\
\hline
\end{tabular}

[a] Standard conditions : $233 \mu \mathrm{L}$ of acetophenone $(2 \mathrm{mmol})$ and $226 \mu \mathrm{L}$ o internal standard (dodecane) in $5 \mathrm{~mL}$ of solvent $\left([\mathrm{PhCOMe}]=3.66 \cdot 10^{-1} \mathrm{M}\right)$, with the appropriate amount of compound 1 and $\mathrm{NaHMDS} / \mathrm{Ru}=1.5, \mathrm{~T}=40^{\circ} \mathrm{C}$; the catalytic mixture was conditioned at the reaction temperature for $15 \mathrm{~min}$ before substrate addition. [b] From the slope of the first order kinetics plot in the linear region

\section{(e) DFT study of the catalytic cycle}

The combined catalytic, spectroscopic and chemical studies point rather firmly to the involvement of the hydride complex $\mathbf{2}$ as the catalytically active species. However, it is impossible to envisage either a Noyori-type (bifunctional and concerted outer-sphere proton/hydride transfer from catalyst to substrate $)^{[19]}$ or a coordination/insertion pathway for this species, because the complex does not contain deprotonatable ligands and is coordinatively saturated. The above described spectroscopic studies suggest facile accessibility of an isopropoxide species from 2 and acetone, either as a neutral O-bonded complex 3 or as an isomeric zwitterionic $\sigma$-complex $\mathbf{6}$. Hence, it is possible to envisage an outer-sphere hydride transfer from 2 to acetophenone via an intermediate $\mathbf{6}^{\prime}$, similar to $\mathbf{6}$, possibly in equilibrium with the O-bonded 1-phenylethoxide isomer, 3'. The 1-phenylethanol product may then be generated by proton exchange with the solvent, which may occur either directly or via the dissociated ion pair (complex [7] ${ }^{+}$and free alkoxide). The latter is suggested by the observation of free [7] in the presence of the less coordinating hexafluoroisopropanolate. Complex 6 then completes the cycle by the reverse hydride transfer process. This catalytic cycle is summarized in Scheme 5 . It is pertinent to remark that catalysts devoid of deprotonatable ligands have already been shown to operate by an outer-sphere ionic mechanism with preliminary hydride transfer, followed by subsequent protonation of the alkoxide intermediate, in ionic hydrogenation (the proton coming in this case from activated $\mathrm{H}_{2}$ ) ${ }^{[20]}$ or in the reverse alcohol and formic acid dehydrogenation. ${ }^{[21]}$ Even Noyori's catalyst itself, though containing a deprotonatable ligand, was suggested to have a similar, non-concerted mechanism with the proton delivered in a subsequent step by $\mathrm{H}_{2}$. ${ }^{[2]}$ 


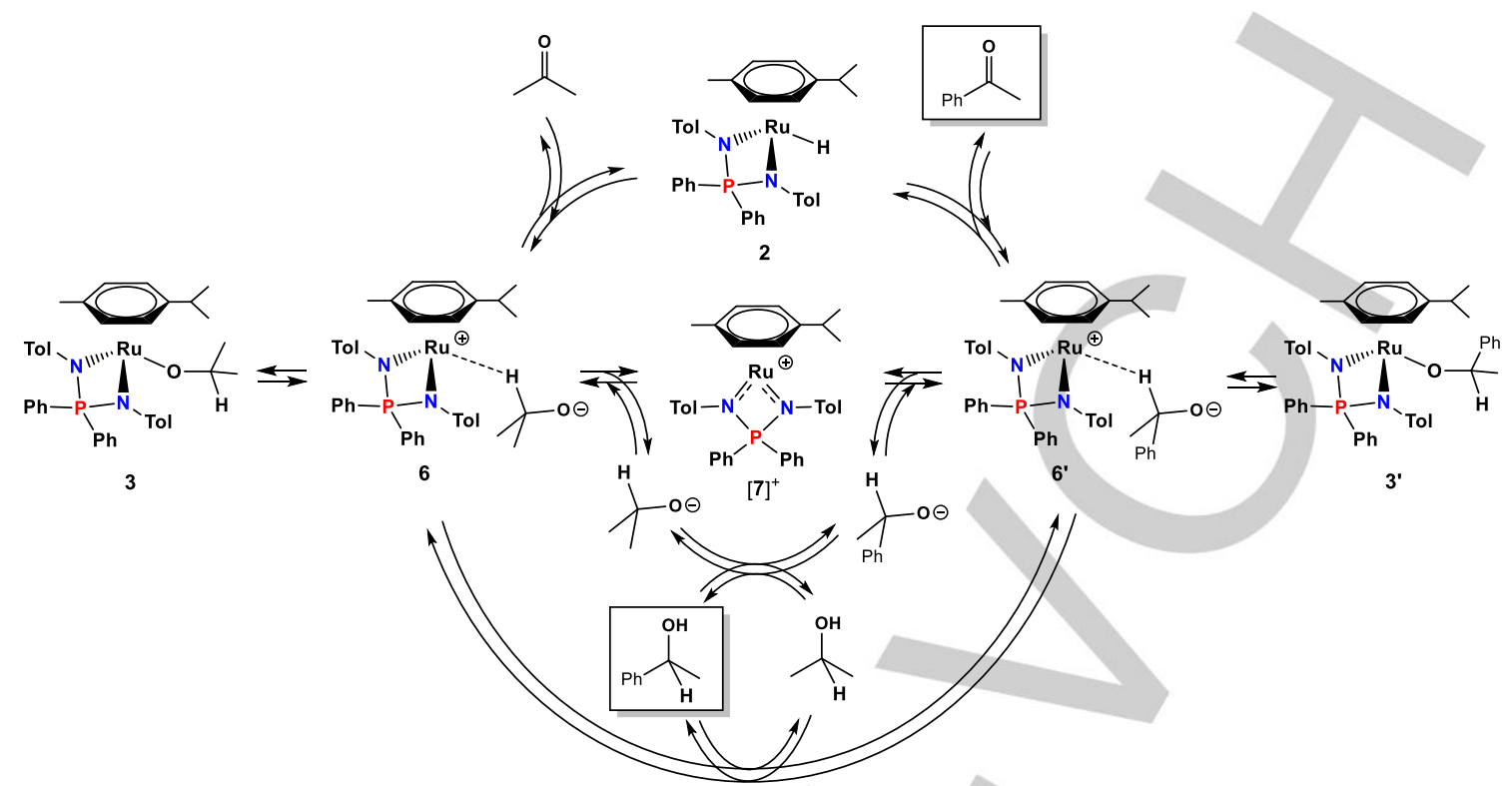

Scheme 5. Proposed mechanism for the catalyzed acetophenone transfer hydrogenation by isopropanol.

The feasibility of this process has been probed by DFT calculations. A first exploration, using the same computational level (B97D functional, basis set, thermal and solvation correction) as above in section (c), shows that the isopropoxide complex 3B (benzene in place of cymene) is more stable than 2B + acetone by $11.9 \mathrm{kcal} / \mathrm{mol}$ on the $E$ scale in the gas phase, but less stable by $7.2 \mathrm{kcal} / \mathrm{mol}$ on the solvation-corrected $G$ scale. Optimization of the benzene model $6 \mathbf{B}$ of the proposed $\sigma$-complex 6 was only possible after explicit introduction of three molecules of $\mathrm{MeOH}$ (computational model of the $\mathrm{PrOH}$ solvent), which stabilize the negative charge of the isopropoxide $\mathrm{O}$ atom by $\mathrm{H}$ bonding, to yield structure $6 \mathrm{~B} \cdot 3 \mathrm{MeOH}$. The importance of the explicit inclusion of alcohol molecules has previously been demonstrated for a related system. ${ }^{[20 \mathrm{a}]}$ In order to compare systems with the same number of molecules, the $\mathrm{Me}_{2} \mathrm{CO} \cdot 3 \mathrm{MeOH}$ and $(\mathrm{MeOH})_{3}$ cluster were also separately optimized. The results are shown in Figure 10. Note that acetone in the $\mathrm{Me}_{2} \mathrm{CO} \cdot 3 \mathrm{MeOH}$ cluster holds only two $\mathrm{MeOH}$ molecules directly $\mathrm{H}$-bonded to the carbonyl $\mathrm{O}$ atom because this has only two available lone pairs. The third $\mathrm{MeOH}$ molecule is $\mathrm{H}$-bonded to one of these $\mathrm{MeOH}$ molecules. The system composed of separate 3B and $(\mathrm{MeOH})_{3}$ is placed at $\Delta G_{\mathrm{iPrOH}, 298 \mathrm{~K}}=7.8 \mathrm{kcal} / \mathrm{mol}$ from the starting $2 \mathrm{~B}+$ $\mathrm{Me}_{2} \mathrm{CO} \cdot 3 \mathrm{MeOH}$ system. The slight difference between this energy change and that from $2 \mathrm{~B}+\mathrm{Me}_{2} \mathrm{CO}$ to $3 \mathrm{~B}(7.2 \mathrm{kcal} / \mathrm{mol})$ is due to the different $\mathrm{H}$-bonding situations within the $\mathrm{Me}_{2} \mathrm{CO} \cdot 3 \mathrm{MeOH}$ and $(\mathrm{MeOH})_{3}$ clusters. As can be seen from Figure $10,6 \mathbf{B} \cdot(\mathrm{MeOH})_{3}$ is at a rather similar energy to the Obonded isopropoxide complex (3B and $\left.(\mathrm{MeOH})_{3}\right)$, in fact it is even slightly preferred. Note, however, that the relative energy of 3B may be lowered by $\mathrm{H}$-bonding interactions with $\mathrm{MeOH}$ molecules, which were not considered in our calculations. Thus, the calculations support the proposition that $\mathbf{6}$ is an accessible system and a minimum on the potential energy surface. Isopropoxide dissociation from $6 \mathrm{~B} \cdot(\mathrm{MeOH})_{3}$ was probed by calculating the separate ions $\mathbf{7}^{\mathbf{H}} \mathbf{B}$ (benzene model of the cymene cationic complex $\left.7^{+}\right)$and the cluster $\mathrm{PrO}^{-} \cdot(3 \mathrm{MeOH})$, which maintains the same $\mathrm{H}$-bonding arrangement as in $6 \mathbf{B} \cdot(\mathbf{M e O H})_{3}$, with the proton of each $\mathrm{MeOH}$ molecule interacting with a separate isopropoxide lone pair. The resulting separate ion pair is at $10.7 \mathrm{kcal} / \mathrm{mol}$ from $2 \mathrm{~B}+\mathrm{Me}_{2} \mathrm{CO} \cdot(\mathrm{MeOH})_{3}$ and at $3.8 \mathrm{kcal} / \mathrm{mol}$ from $6 \mathrm{~B} \cdot(\mathrm{MeOH})_{3}$ or $2.9 \mathrm{kcal} / \mathrm{mol}$ from $3 \mathrm{~B}+(\mathrm{MeOH})_{3}$ on the $\Delta G_{\mathrm{iPrOH}, 298 \mathrm{~K}}$ scale. Without the three $\mathrm{H}$-bonded $\mathrm{MeOH}$ molecules, alkoxide dissociation from 3B to yield $\mathbf{7}^{+} \mathbf{B}+$ PrO $^{-}$(both still considered with solvation correction in $\mathrm{PrOH}$ ) becomes uphill by $29.6 \mathrm{kcal} / \mathrm{mol}$. These results clearly show that hydrogen bonding from the alcohol solvent provides the driving force toward alkoxide dissociation.

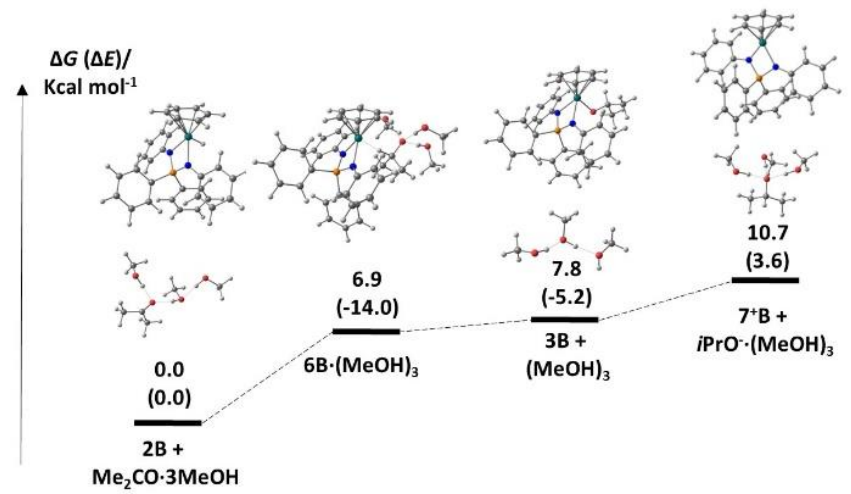

Figure 10. Relative energies ( $\Delta G_{\mathbb{P r O H}, 298 \mathrm{~K}}$, with gas phase $\Delta E$ in parentheses) of systems of relevance for the ketone transfer hydrogenation catalyzed by complex 2 .

The transition state for the hydride transfer process from 2B to acetone could not be located/optimized. Attempts to optimize 
this stationary point on an even more simplified system ( $\mathrm{H}$ atoms replacing the $\mathrm{Ph}$ and Tol substituents on the NPN ligand, symbolized as HB) also failed. Thus, we have explored the reaction pathway with a series of partial optimizations (relaxed scan), keeping the $\mathrm{C}-\mathrm{H}$ distance at different fixed values. Starting from the optimized $6 \mathrm{HB} \cdot 3 \mathrm{MeOH}$, the $\mathrm{C}-\mathrm{H}$ distance was increased stepwise, resulting in an energy increase up to a distance of 1.688 $\AA$, then to a decrease, see Figure 11 (blue points). Full optimization starting from the final point at $\mathrm{C}-\mathrm{H}=1.938$ afforded the van der Waals adduct of $2 \mathrm{HB}$ with the $\mathrm{Me}_{2} \mathrm{CO} \cdot 3 \mathrm{MeOH}$ cluster, where one $\mathrm{MeOH}$ molecule has shifted from the $\mathrm{O}$ atom of isopropanolate (which now become the acetone carbonyl $\mathrm{O}$ atom) to another $\mathrm{MeOH}, \mathbf{2 H B} \cdot \mathbf{M e}{ }_{2} \mathbf{C O} \cdot(2+1) \mathbf{M e O H}$. The hydride ligand is at 2.56 and $2.58 \AA$ from two $\mathrm{H}$ atoms and at $2.62 \AA$ from the carbonyl $C$ atom of acetone, as highlighted in Figure 11. This local minimum is set as the zero energy reference point; the highest point along the reaction coordinate is higher by only $5.7 \mathrm{kcal} / \mathrm{mol}$. Complex $6 \mathrm{HB}$ was also reoptimized in the presence of the same $\mathrm{H}$-bonding environment to yield a local minimum, $6 \mathrm{HB} \cdot(2+1) \mathrm{MeOH}$, at a slightly lower $E$, but slightly higher GiproH,298k. A new relaxed scan on the $\mathrm{C}-\mathrm{H}$ distance was carried out starting from this point (purple points in Figure 11), yielding a qualitatively similar behavior with the highest energy point found at approximately the same $\mathrm{C}-\mathrm{H}$ distance $(1.677 \AA)$, but at even lower energy, $2.5 \mathrm{kcal} / \mathrm{mol}$. Since the transition states could not be located, the $G^{t}{ }_{i P r O H, 298 K}$ values could not be determined. The calculations, however, clearly suggest that the transformations of 2 to 6 and vice versa require very low activation and should therefore be relatively rapid processes, in agreement with the above given interpretation of the NMR results in acetone[ $\left.D_{6}\right]$. The other part of the cycle (proton transfer leading from 6' and $\mathrm{PrOH}$ to 6 and $\mathrm{PhCH}(\mathrm{Me}) \mathrm{OH}$ ) was not modelled by DFT, because of the computational challenge with the need to include a number of explicit solvent molecules in the system. Given the approximations, it would also be difficult to compare the intra- and intermolecular pathways. Processes involving pseudodegenerate proton transfers between alkoxide anions, however, are not expected to involve high energy barriers.

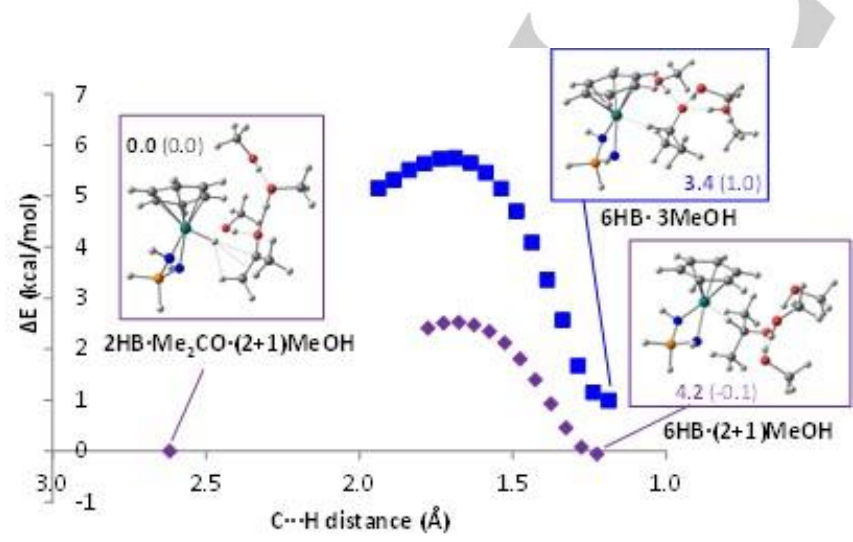

Figure 11. Computational exploration of the hydride transfer from $2 \mathrm{HB}$ to acetone leading to $6 \mathrm{HB}$. The values indicated for the three local minima are the relative $G_{\mathbb{P r O H}, 298 \mathrm{~K}}$ (in bold characters) and relative gas phase $E$ (in parentheses) in $\mathrm{kcal} / \mathrm{mol}$.

\section{Conclusions}

The present contribution has analyzed the action of an $\left(\eta^{6}\right.$ cymene)ruthenium chloride complex supported by a chelating iminophosphonamide ligand, $\left[\left(\eta^{6}-\mathrm{Cym}\right) \mathrm{RuCl}(\mathbf{N P N})\right](\mathbf{1})$, as a precatalyst for ketone transfer hydrogenation by isopropanol, demonstrating that the active catalyst is a hydride species $\left[\left(n^{6}\right.\right.$ Cym)RuH(NPN)] (2). Although this hydride species is unstable with respect to isomerization to a 16-electron cyclohexadienyl system by hydride migration to the arene ring, it is stabilized by dihydrogen bonding in isopropanol. The complex catalyzes efficiently the transfer hydrogenation of acetophenone and remains stable long enough in the $25-80^{\circ} \mathrm{C}$ temperature range to provide linear first order behavior to high conversion. The most relevant result of this study is the elucidation of the transfer hydrogenation mechanism by a combination of NMR investigations and DFT calculations. It constitutes, to the best of our knowledge, the first detailed mechanistic investigation of an outer-sphere transfer hydrogenation for a catalyst devoid of deprotonatable ligands, showing that the hydride ligand can be delivered to the outer-sphere ketone with $\mathrm{H}$-bonding assistance by the isopropanol solvent, which then completes the process by protonation in a second step.

\section{Experimental Section}

General procedures. All manipulations were carried out using standard Schlenk techniques under an atmosphere of dry argon. Solvents were purified by standard methods and distilled prior to use. ${ }^{1} \mathrm{H},{ }^{31} \mathrm{P}$ and ${ }^{13} \mathrm{C}$ NMR spectra were obtained on Bruker Avance 300 and Bruker AvancellI 400 spectrometers and referenced to the residual signals of deuterated solvent $\left({ }^{1} \mathrm{H}\right.$ and $\left.{ }^{13} \mathrm{C}\right)$, and to $85 \% \mathrm{H}_{3} \mathrm{PO}_{4}\left({ }^{31} \mathrm{P}\right.$, external standard). Compounds $\left.\quad\left[\left(\eta^{6}-\mathrm{Cym}\right) \mathrm{RuCl}(\mathbf{N P N})\right] \quad(\mathbf{1}),{ }^{[9]} \quad\left[\left(\eta^{6}-\mathrm{Cym}\right) \mathrm{Ru}(\mathbf{N P N})\right\}\right]^{+} \mathrm{PF}_{6}$ $\left([7] \mathrm{PF}_{6}\right)^{[9]}$ and $\left[\left(\eta^{6}-\mathrm{Cym}\right) \mathrm{RuCl}_{2}\right]_{2}{ }^{[23]}$ were prepared according to described procedures.

Synthesis of $\left[\left(\eta^{6}-p\right.\right.$-cymene $) \mathrm{Ru}\left\{\mathrm{Ph}_{2} \mathrm{P}\left(\mathrm{N}-p-\mathrm{Tol}_{2}\right\}\right]^{+} \mathrm{BF}_{4}^{-} \quad\left([7] \mathrm{BF}_{4}\right)$. Complex $[7] \mathrm{BF}_{4}$ was obtained by adapting the procedure previously reported for [7] $\mathrm{PF}_{6}{ }^{\left[{ }^{[9]}\right.} \mathrm{To}$ a solution of $\mathbf{1}(0.27 \mathrm{~g}, 0.40 \mathrm{mmol})$ in $\mathrm{CH}_{2} \mathrm{Cl}_{2}(20$ $\mathrm{ml}$ ) solid $\mathrm{TIBF}_{4}(0.24 \mathrm{~g}, 0.81 \mathrm{mmol})$ was added causing the color to immediately change from red to deep blue. The reaction mixture was stirred for $3 \mathrm{~h}$ and then filtered through a bed of Celite. The solution was concentrated to $5 \mathrm{~mL}$, further addition of $\mathrm{Et}_{2} \mathrm{O}(30 \mathrm{~mL})$ resulted in precipitation of a blue-black microcrystalline, which was filtered off, washed with $\mathrm{Et}_{2} \mathrm{O}(2 \times 5 \mathrm{~mL})$ and dried in vacuum. Yield of [7]BF $4: 0.27 \mathrm{~g}$ (93\%). The ${ }^{1} \mathrm{H}$ and ${ }^{31} \mathrm{P}$ NMR properties of this compound perfectly match those reported previously for the analogous $\mathrm{PF}_{6}{ }^{-}$salt. ${ }^{[9]}$

In situ generation of $\left[\left(\eta^{6}-p\right.\right.$-cymene $\left.) \mathrm{RuH}\left\{\mathrm{Ph}_{2} \mathrm{P}(\mathrm{N}-p-\mathrm{Tol})_{2}\right\}\right]$ (2). The hydride complex 2 was generated in situ in a NMR tube. To a solution of the chloride complex 1 (13 mg, $0.020 \mathrm{mmol})$ in $\mathrm{C}_{6} \mathrm{D}_{6}(0.5 \mathrm{~mL})$ a NaHMDS solution $(2.0 \mathrm{M}$ in THF, $0.015 \mathrm{~mL}, 0.030 \mathrm{mmol})$ and isopropanol $(0.80$ $\mathrm{mmol}, 0.06 \mathrm{~mL}$ ) were added. The resulting suspension was vigorously shaken for $15 \mathrm{~min}$ at room temperature to complete the dissolution of $\mathbf{1}$ yielding a yellow solution. According to the NMR spectra, the yield of complex 2 is $95-98 \% .{ }^{31} \mathrm{P}$ NMR $\left(\mathrm{C}_{6} \mathrm{D}_{6}\right): \delta 33.2 .{ }^{1} \mathrm{H}$ NMR $\left(\mathrm{C}_{6} \mathrm{D}_{6}\right): \delta 8.16(\mathrm{~m}$, $2 \mathrm{H}, o-\mathrm{HPh}_{\mathrm{Ph}}, 7.61\left(\mathrm{ddd},{ }^{3} \mathrm{~J}_{\mathrm{HP}}=11.0,{ }^{3} \mathrm{~J}_{H H}=8.0,{ }^{4} \mathrm{~J}_{H H}=1.6,2 \mathrm{H}, o^{\prime}-\mathrm{HPh}_{\mathrm{Ph}}\right), 7.25$ $(\mathrm{m}, 3 \mathrm{H},(p+m)-\mathrm{Hph}), 6.82\left(\mathrm{~m}, 3 \mathrm{H},(p+m)^{\prime}-\mathrm{Hph}\right), 6.79\left(\mathrm{~d},{ }^{3} \mathrm{HH}=8.0,4 \mathrm{H}\right.$, $\left.\left(\mathrm{C}_{6} \mathrm{H}_{4}\right)_{\mathrm{tol}}\right), 6.73\left(\mathrm{dd},{ }^{3} \mathrm{~J}_{H H}=8.0,{ }^{4} \mathrm{~J}_{H P}=1.2,4 \mathrm{H},\left(\mathrm{C}_{6} \mathrm{H}_{4}\right)_{\mathrm{tol}}\right), 4.89\left(\mathrm{~d},{ }^{3} \mathrm{~J}_{H H}=5.6\right.$, $\left.2 \mathrm{H},\left(\mathrm{C}_{6} \mathrm{H}_{4}\right)_{\mathrm{cym}}\right), 4.82\left(\mathrm{~d},{ }^{3} \mathrm{JHH}_{\mathrm{H}}=5.6,2 \mathrm{H},\left(\mathrm{C}_{6} \mathrm{H}_{4}\right)_{\mathrm{cym}}\right), 2.65\left(\mathrm{sept},{ }^{3} \mathrm{~J}_{H H}=6.8\right.$, 
$\left.1 \mathrm{H}, \mathrm{CH}-\mathrm{Me}_{2}\right), 2.08\left(\mathrm{~s}, 3 \mathrm{H}, \mathrm{Me}_{\text {cym }}\right), 2.08\left(\mathrm{~s}, 6 \mathrm{H}, \mathrm{Me}_{\mathrm{tol}}\right), 1.29\left(\mathrm{~d},{ }^{3} \mathrm{JHH}_{\mathrm{H}}=6.8\right.$, $\left.6 \mathrm{H}, \overline{\mathrm{CH}}-\underline{\mathrm{Me}_{2}}\right),-3.07$ (s, Ru-H). ${ }^{13} \mathrm{C}$ NMR $\left(\mathrm{C}_{6} \mathrm{D}_{6}\right): \delta 148.7$ (d, ${ }^{2} \mathrm{~J}_{\mathrm{CP}}=5.1, i^{\prime \prime}-$ $\left.\mathrm{C}_{\text {tol }}\right), 135.9\left(\mathrm{~d},{ }^{1} J_{C P}=92.4, i-\mathrm{C}_{\mathrm{Ph}}\right), 133.1\left(\mathrm{~d},{ }^{2} \mathrm{~J}_{C P}=9.2, o^{\prime}-\mathrm{C}_{\mathrm{Ph}}\right), 132.6(\mathrm{~d}$, $\left.{ }^{2} J_{C P}=10.4, o-C_{P h}\right), 131.8\left(d,{ }^{4} J_{C P}=2.7, p-C_{P h}\right), 131.4\left(d,{ }^{4} J_{C P}=2.7, p\right.$ ' $\mathrm{CPh}_{\mathrm{Ph}}, 129.1\left(\mathrm{~s}, m^{\prime \prime}-\mathrm{C}_{\mathrm{tol}}\right), 128.9\left(\mathrm{~d},{ }^{3} \mathrm{~J}_{C P}=11.5, m-\mathrm{CPh}_{\mathrm{Ph}}\right), 126.5\left(\mathrm{~d},{ }^{5} \mathrm{~J}_{C P}=1.1\right.$, p"--Col), 123.5 (d, $\left.{ }^{3} J_{C P}=11.1, o^{\prime \prime}-C_{\text {tol }}\right), 106.5$ (s, $\left.\mathrm{C}_{\text {cym }}\right), 99.7$ (s, $\left.\mathrm{C}_{\text {cym }}\right), 80.3$ (s, $\mathrm{CH}_{\text {cym }),} 76.2$ (s, $\left.\mathrm{CH}_{\text {cym }}\right), 32.7$ (s, $\left.\underline{\mathrm{CH}}-\mathrm{Me}\right), 24.0$ (s, CH-Me), 20.6 (s, Metol), 20.1 (s, Mecym). IR spectrum ( $\left.\mathrm{C}_{6} \mathrm{D}_{6}\right)$ : VRuH $1880 \mathrm{~cm}^{-1}$.

Transformation of 2 into a mixture of $\left[\left(\eta^{5}-\mathrm{C}_{6} \mathrm{H}_{5}-1-\mathrm{Me}-4-\mathrm{Pr}\right) \mathrm{Ru}\left\{\mathrm{Ph}{ }_{2} \mathrm{P}(\mathrm{N}\right.\right.$ $p$-Tol $\left.\left.)_{2}\right\}\right]$ (4) and $\left[\left(\eta^{5}-\mathrm{C}_{6} \mathrm{H}_{5}-1-\mathrm{Pr}-4-\mathrm{Me}\right) \mathrm{Ru}\left\{\mathrm{Ph}_{2} \mathrm{P}(\mathrm{N}-p-\mathrm{Tol})_{2}\right\}\right]$ (4'). In a Schlenk tube containing a solution of NaHMDS $(2.0 \mathrm{M}$ in THF, $0.045 \mathrm{~mL}$, $0.09 \mathrm{mmol}$ ) in isopropanol/toluene $(2.5 / 2.5 \mathrm{~mL})$, the chloride complex $1(50$ $\mathrm{mg}, 0.075 \mathrm{mmol}$ ) was added and the resulting suspension was stirred for $40 \mathrm{~min}$ at room temperature. The solvent was removed under reduced pressure, the solid residue was dried and then extracted with deuterated benzene $(2 \mathrm{~mL})$. The precipitate was filtered off and the filtrate was kept at $40^{\circ} \mathrm{C}$ for 1 day. According to the NMR spectra in $\mathrm{C}_{6} \mathrm{D}_{6}$, the product consists of a mixture of two regioisomers 4 and $\mathbf{4}^{\prime}$ and residual complex 2 in a ratio $4: 4^{\prime}: 2=55: 15: 30 .{ }^{31} \mathrm{P}$ NMR $\left(\mathrm{C}_{6} \mathrm{D}_{6}\right): \delta 50.6(4), 51.1\left(4^{\prime}\right)$. The assignment of the resonances to compounds 4 and 4 ' was based on the detailed analysis of ${ }^{31} \mathrm{P},{ }^{1} \mathrm{H},{ }^{13} \mathrm{C}\left\{{ }^{1} \mathrm{H}\right\},{ }^{1} \mathrm{H}-{ }^{1} \mathrm{H}$ COSY and ${ }^{1} \mathrm{H}-{ }^{13} \mathrm{C}$ HSQC NMR spectra (see details in the Supporting Information). In the ${ }^{1} \mathrm{H}$ NMR spectrum, the aromatic P-phenyl and N-tolyl resonances of the NPN ligands of compounds 4 and $\mathbf{4}^{\prime}$ overlap and are observed at $\delta 7.80(\mathrm{~m}, 4 \mathrm{H}, \mathrm{o}-\mathrm{H}), 6.97$ $(\mathrm{m}, 6 \mathrm{H}, m, p-\mathrm{H}), 7.09\left(\mathrm{~d},{ }^{3} \mathrm{~J}=7.8,4 \mathrm{H}, o^{\prime}-\mathrm{H}\right), 6.85\left(\mathrm{~d},{ }^{3} \mathrm{~J}=7.8,4 \mathrm{H}, m^{\prime}-\mathrm{H}\right)$. ${ }^{1} \mathrm{H}$ NMR for $4\left(\mathrm{C}_{6} \mathrm{D}_{6}\right): \delta 6.03\left(\mathrm{~d},{ }^{3} \mathrm{~J}=4.8,1 \mathrm{H}, \mathrm{Hb}_{\mathrm{b}}\right), 3.93\left(\mathrm{~d},{ }^{3} \mathrm{~J}=4.8,1 \mathrm{H}, \mathrm{H}_{\mathrm{a}}\right)$, $2.92\left(\mathrm{~d},{ }^{3} \mathrm{~J}=6.0,1 \mathrm{H}, \mathrm{H}_{\mathrm{j}}\right), 2.67\left(\mathrm{dd},{ }^{2} \mathrm{~J}=13.2,{ }^{3} \mathrm{~J}=6.6,1 \mathrm{H}, \mathrm{Hen}_{\mathrm{en}}, 2.05(\mathrm{~s}\right.$, $\left.6 \mathrm{H}, \mathrm{Me}_{\mathrm{h}}\right), 1.94$ (sept, $\left.{ }^{3} \mathrm{~J}=6.6,1 \mathrm{H}, \mathrm{CH}_{\mathrm{f}}\right), 1.38\left(\mathrm{~d},{ }^{3} \mathrm{~J}=6.6,3 \mathrm{H}, \mathrm{Me}_{\mathrm{g}}\right), 1.36$ $\left(\mathrm{s}, 3 \mathrm{H}, \mathrm{Me}_{\mathrm{e}}\right), 1.28\left(\mathrm{~d},{ }^{2} \mathrm{JHH}=13.2,1 \mathrm{H}, \mathrm{Hex}_{\mathrm{ex}}\right), 1.13\left(\mathrm{~d},{ }^{3} \mathrm{JHH}=6.6,3 \mathrm{H}, \mathrm{Me}_{\mathrm{g}^{\prime}}\right)$. ${ }^{1} \mathrm{H}$ NMR for 4 ' $\left(\mathrm{C}_{6} \mathrm{D}_{6}\right): \delta 5.93\left(\mathrm{~d},{ }^{3} \mathrm{~J}=4.8,1 \mathrm{H}, \mathrm{H}_{\mathrm{b}}\right), 3.88\left(\mathrm{~d},{ }^{3} \mathrm{~J}=4.8,1 \mathrm{H}\right.$, $\left.\mathrm{H}_{\mathrm{a}}\right), 2.96\left(\mathrm{~d},{ }^{3} \mathrm{~J}=6.0,1 \mathrm{H}, \mathrm{H}_{\mathrm{j}}\right), 2.72\left(\mathrm{dd},{ }^{2} \mathrm{~J}=13.2,{ }^{3} \mathrm{~J}=6.6,1 \mathrm{H}, \mathrm{H}_{\mathrm{en}}\right), 2.04$ $\left(\mathrm{s}, 6 \mathrm{H}, \mathrm{Me}_{\mathrm{h}}\right), 1.78\left(\mathrm{~s}, 3 \mathrm{H}, \mathrm{Me}_{\mathrm{e}}\right), 1.74\left(\mathrm{~m}, 1 \mathrm{H}, \mathrm{CH}_{\mathrm{f}}\right), 1.71\left(\mathrm{~d},{ }^{3} \mathrm{~J}=6.6,3 \mathrm{H}\right.$, $\left.\mathrm{Me}_{\mathrm{g}^{\prime}}\right), 1.02\left(\mathrm{~d},{ }^{2} \mathrm{~J}=13.2,1 \mathrm{H}, \mathrm{Hex}_{\mathrm{ex}}\right), 0.90\left(\mathrm{~d},{ }^{3} \mathrm{~J}=6.6,3 \mathrm{H}, \mathrm{Me}_{\mathrm{g}}\right) .{ }^{13} \mathrm{C}$ NMR for $4\left(\mathrm{C}_{6} \mathrm{D}_{6}\right): \delta 147.2\left(\mathrm{~d},{ }^{2} \mathrm{~J}_{C P}=5.3, i^{\prime}-\mathrm{C}\right), 132.4\left(\mathrm{~d},{ }^{2} J_{C P}=9.6, o-\mathrm{C}\right), 131.9(\mathrm{~d}$, $\left.{ }^{4} J_{C P}=2.0, p-C\right), 131.8\left(\mathrm{~d},{ }^{1} J_{C P}=86.4, i-\mathrm{C}\right), 129.2\left(\mathrm{~s}, m^{\prime}-\mathrm{C}\right), 128.5\left(\mathrm{~d},{ }^{3} J_{C P}\right.$ $=11.0, m-\mathrm{C}), 126.6\left(\mathrm{~s}, p^{\prime}-\mathrm{C}\right), 125.0\left(\mathrm{~d},{ }^{3} J_{C P}=9.8, o^{\prime}-\mathrm{C}\right), 92.4\left(\mathrm{~s}, C_{\mathrm{d}}\right), 76.4$ (s, $\left.\mathrm{CH}_{\mathrm{a}}\right), 70.2\left(\mathrm{~s}, \mathrm{CH}_{\mathrm{b}}\right), 38.4\left(\mathrm{~s}, \mathrm{CH}_{2(\mathrm{k})}\right), 37.5\left(\mathrm{~s}, i-\mathrm{C}_{\mathrm{c}}\right), 32.7\left(\mathrm{~s}, \mathrm{CH}_{\mathrm{f}}\right), 29.2$ (s, $\left.\mathrm{CH}_{\mathrm{j}}\right), 25.3\left(\mathrm{~s}, \mathrm{Me}_{\mathrm{e}}\right), 24.9\left(\mathrm{~s}, \mathrm{Me}_{\mathrm{g}}\right), 22.4\left(\mathrm{~s}, \mathrm{Me}_{\mathrm{g}}\right), 20.8\left(\mathrm{~s}, \mathrm{Me}_{\mathrm{h}}\right) .{ }^{13} \mathrm{C} \mathrm{NMR}$ for 4' $\left(\mathrm{C}_{6} \mathrm{D}_{6}\right): \delta 147.0\left(\mathrm{~d},{ }^{2} J_{C P}=5.1, i^{\prime}-\mathrm{C}\right), 132.5\left(\mathrm{~d},{ }^{2} J_{C P}=9.6, o-C\right), 131.9$ (overlapped, $p$-C), $129.3\left(\mathrm{~s}, m^{\prime}-\mathrm{C}\right), 128.4$ (d, overlapped, $m-\mathrm{C}$ ), 126.6 (s, overlapped, $\left.p^{\prime}-\mathrm{C}\right), 125.1\left(\mathrm{~d},{ }^{3} J_{C P}=9.8, o^{\prime}-\mathrm{C}\right), 82.6\left(\mathrm{~s}, C_{\mathrm{d}}\right), 75.4\left(\mathrm{~s}, \mathrm{CH}_{\mathrm{a}}\right)$, $73.1\left(\mathrm{~s}, \mathrm{CH}_{\mathrm{b}}\right), 47.8\left(\mathrm{~s}, \mathrm{C}_{\mathrm{c}}\right), 35.2\left(\mathrm{~s}, \mathrm{CH}_{\mathrm{f}}\right), 30.8\left(\mathrm{~s}, \mathrm{CH}_{\mathrm{j}}\right), 30.4\left(\mathrm{~s}, \mathrm{CH}_{2(\mathrm{k})}\right), 22.1$ (s, Me $\left.\mathrm{g}^{\prime}\right), 20.9$ (s, Me $\mathrm{e}_{\mathrm{e}}$ ), $20.3\left(\mathrm{~s}, \mathrm{Me}_{\mathrm{g}}\right.$ ), 20.6 (s, overlapped, Men). The detailed spectra are shown in the SI (Figures S8-S12).

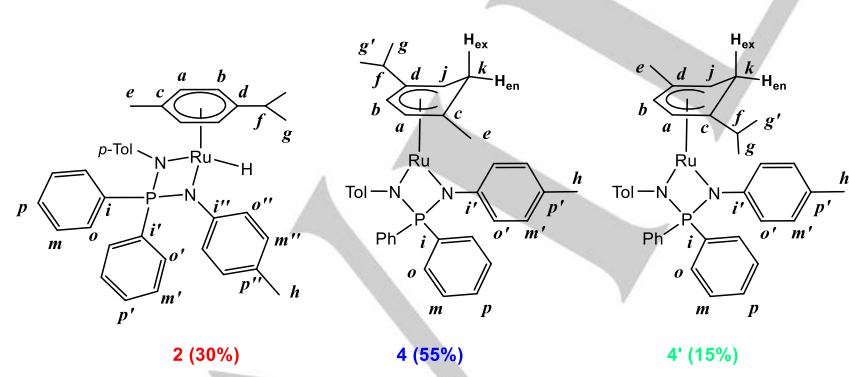

Alternative method for generation of 2. To a Schlenk tube containing a suspension of $1(20 \mathrm{mg}, 0.030 \mathrm{mmol})$ in toluene $(3 \mathrm{~mL}), \mathrm{NaEt} 3 \mathrm{BH}(1.0 \mathrm{M}$ in toluene, $0.036 \mathrm{~mL}, 0.036 \mathrm{mmol}$ ) was added, and the resulting mixture was stirred for $1 \mathrm{~h}$ at room temperature. The precipitate was filtered off, the filtrate was evaporated to dryness under reduced pressure and the residue was dried in vacuo. According to ${ }^{31} \mathrm{P} N \mathrm{NMR}\left(\mathrm{C}_{6} \mathrm{D}_{6}\right)$ the final product contains $2, \mathbf{4}$ and $\mathbf{4}^{\prime}$ 'in a 35:57:8 ratio.
X-ray crystallography. A freshly prepared mixture of 2, $\mathbf{4}$ and 4' was dissolved in neat $\mathrm{PrOH}$ and the solution was allowed to stay for crystallization for 3 days at room temperature. A red crystals thus obtained was mounted under inert perfluoropolyether at the tip of glass fiber and cooled in the cryostream of a CAD4 Nonius diffractometer fitted with the APEX II CCD. The structure was solved by using the integrated spacegroup and crystal structure determination SHELXt software ${ }^{24]}$ and refined by least-squares procedures on $F^{2}$ using SHELXL-2014. ${ }^{[25]}$ The asymmetric unit contains two independent Ru complexes with roughly similar geometry. The crystal was poorly diffracting and no significant intensities could be detected above $24^{\circ}$ in theta. Moreover, the crystal is a mixture of two isomers as shown by NMR (see Results and Discussion). The occurrence of these two isomers induced a diffused disorder in the cyclohexadienyl rings, the conformation of which was difficult to define. It was impossible to correctly model the disorder. Therefore, the cyclohexadienyl rings were refined using severe restraints on the anisotropic thermal parameters to avoid large thermal ellipsoids. Owing to the poor quality of the data, the phenyl rings in the NPN ligands were treated as rigid group with idealized C-C distances of $1.39 \AA$ and C-C-C angles of $120^{\circ}$, in order to minimize the number of refined parameters. As the space group is non centrosymmetric, the Flack parameter ${ }^{[26]}$ was refined yielding a value of $0.21(8)$, which indicates twinning by inversion. This phenomenon may also be related to the presence of a mixture of the two isomers. All $\mathrm{H}$ atoms attached to $\mathrm{C}$ atoms were introduced in the calculation at idealised positions and treated as riding models. The molecule drawing was realised with the help of ORTEP32. ${ }^{[27]}$ Crystal data and refinement parameters are shown in Tables 1. Crystallographic data (excluding structure factors) have been deposited with the Cambridge Crystallographic Data Centre as supplementary publication no. CCDC 1583403. Copies of the data can be obtained free of charge on application to the Director, CCDC, 12 Union Road, Cambridge CB2 1EZ, UK (fax: (+44) 1223-336-033; e-mail: deposit@ccdc.cam.ac.uk).

Catalytic studies. In a typical experiment, the precatalyst 1 or $[\mathbf{5}]^{+}(0.02$ $\mathrm{mmol}$ ) was suspended in $\mathrm{PrOH}(5 \mathrm{~mL})$ or $\mathrm{PrOH} /$ toluene $(2.5 / 2.5 \mathrm{~mL})$ and then treated (if appropriate) with a $2.0 \mathrm{M}$ solution of NaHMDS in THF in the amounts given in Table 4. In the presence of base, the mixture was preliminary stirred at room temperature for 40 minutes, then it was warmed to the desired temperature followed by the addition of dodecane $(1 \mathrm{mmol}$, $0.225 \mathrm{ml})$ and acetophenone $(2 \mathrm{mmol}, 0.233 \mathrm{ml})$. Aliquots $(0.1 \mathrm{~mL})$ were taken at the times specified in Table 3, diluted with diethyl ether $(0.8 \mathrm{~mL})$ and filtered through a silica bed. The reaction samples were analyzed by GC equipped with J\&W GC Column with a DB-1MS stationary phase (program: $25 \mathrm{~min}$ at $50{ }^{\circ} \mathrm{C}$, with further heating rate $20^{\circ} \mathrm{C} / \mathrm{min}$ to $170{ }^{\circ} \mathrm{C}$ retention times: $T($ acetophenone $)=24 \mathrm{~min}, T(1-$ phenylethanol $)=25 \mathrm{~min}$, $T($ dodecane $)=31 \mathrm{~min})$.

Computational details. The calculations were carried out within the DFT approach with M06L[28] and 97D[29] functionals in Gaussian 09.[30] All geometry optimizations were carried out using the LANL2DZ basis set and ECP for the $\mathrm{Ru}$ atom, ${ }^{[31]}$ augmented with an $\mathrm{f}$ polarization function $(\alpha=$ $1.235){ }^{[32]}$ and the $6-311 \mathrm{G}(\mathrm{d}, \mathrm{p})^{[33]}$ basis sets for all other atoms. Calculations were corrected for dispersion interactions by Grimme's D3 ${ }^{[16]}$ method for M06L whereas the B97D functional already considers dispersion. The effect of the solvent was included by the SMD polarisable continuum ${ }^{[34]}$ in isopropanol $(\varepsilon=19,264)$. All of the energies presented in the text are Gibbs energies in isopropanol ( $\left.\Delta \mathrm{G}_{\mathrm{iPrOH}}\right)$.

\section{Acknowledgements}

The authors thank the Centre National de la Recherche Scientifique (CNRS), the Institut Universitaire de France (IUF), 
and the Russian Science Foundation (grant no. 14-13-00801) for financial support. This work was granted access to the HPC resources of IDRIS under the allocation 2017-086343 made by GENCI (Grand Equipement National de Calcul Intensif) and to the resources of the CICT (Centre Interuniversitaire de Calcul de Toulouse, project CALMIP). I.S. thanks the French Ministry of Foreign Affairs for a Ph.D. scholarship through the French Embassy in Moscow.

Keywords: Ruthenium • Iminophosphonamide ligand $\bullet p$ Cymene ligand $\bullet$ Transfer hydrogenation $\cdot$ DFT calculations

[1] K. J. Haack, S. Hashiguchi, A. Fujii, T. Ikariya and R. Noyori, Angew. Chem. Int. Ed. Engl. 1997, 36, 285-288.

[2] W. Baratta, P. Da Ros, A. Del Zotto, A. Sechi, E. Zangrando and P. Rigo, Angew. Chem. Int. Ed. Engl. 2004, 43, 3584-3588.

[3] W. Baratta, G. Chelucci, S. Magnolia, K. Siega and P. Rigo, Chem. Eur. J. 2009, 15, 726-732

[4] R. J. Lundgren, M. A. Rankin, R. McDonald, G. Schatte and M. Stradiotto, Angew. Chem. Int. Ed. Engl. 2007, 46, 4732-4735.

[5] a) R. Noyori and S. Hashiguchi, Acc. Chem. Res. 1997, 30, 97-102; b) R. Noyori and T. Ohkuma, Angew. Chem. Int. Ed. Engl. 2001, 40, 40-73.

[6] T. y. A. Peganova, A. V. Valyaeva, A. M. Kalsin, P. V. Petrovskii, A. O. Borissova, K. A. Lyssenko and N. A. Ustynyuk, Organometallics 2009 28, 3021-3028.

[7] P. J. Bailey, K. J. Grant and S. Parsons, Organometallics 1998, 17, 551 555.

[8] T. A. Peganova, I. S. Sinopalnikova, A. S. Peregudov, I. V. Fedyanin, A. Demonceau, N. A. Ustynyuk and A. M. Kalsin, Dalton Trans. 2016, 45, 17030-17041.

[9] I. S. Sinopalnikova, T. y. A. Peganova, V. V. Novikov, I. V. Fedyanin, O. A. Filippov, N. V. Belkova, E. S. Shubina, R. Poli and A. M. Kalsin, Chem. Eur. J. 2017, $15424-15435$.

[10] O. V. Gusev, T. A. Peganova, A. V. Gonchar, P. V. Petrovskii, K. A. Lyssenko and N. A. Ustynyuk, Phosphorus Sulfur and Silicon and the Related Elements 2009, 184, 322-331.

[11] a) L. M. Epstein, N. V. Belkova and E. S. Shubina in Dihydrogen Bonded Complexes and Proton Transfer to Hydride Ligands by Spectral (IR, NMR) Studies, Eds.: M. Peruzzini and R. Poli), Elsevier, Amsterdam, 2001, pp. 391-418; b) N. V. Belkova, L. M. Epstein and E. S. Shubina, Eur. J. Inorg. Chem. 2010, 3555-3565.

[12] a) N. V. Belkova, L. M. Epstein, O. A. Filippov and E. S. Shubina, Chem Rev. 2016, 116, 8545-8587; b) N. V. Belkova, O. A. Filippov and E. S. Shubina, DOI: $10.1002 /$ chem. 201704203 .

[13] T. Arthur, D. R. Robertson, D. A. Tocher and T. A. Stephenson, J. Organomet. Chem. 1981, 208, 389-400.

[14] A. D. Phillips, O. Zava, R. Scopelitti, A. A. Nazarov and P. J. Dyson, Organometallics 2010, 29, 417-427.

[15] W. Kitikiatsophon and P. Piumsomboon, ScienceAsia 2004, 30, 135-147.

[16] S. Grimme, J. Antony, S. Ehrlich and H. Krieg, J. Chem. Phys. 2010, 132.

[17] a) S. E. Clapham, A. Hadzovic and R. H. Morris, Coord. Chem. Rev. 2004, 248, 2201-2237; b) J. S. M. Samec, J. E. Backvall, P. G. Andersson and P. Brandt, Chem. Soc. Rev. 2006, 35, 237-248.
[18] M. A. Bennett, T. N. Huang and T. W. Turney, Chem. Commun. 1979 312-314.

[19] M. Yamakawa, H. Ito and R. Noyori, J. Am. Chem. Soc. 2000, 122, 14661478.

[20] a) J. M. Hayes, E. Deydier, G. Ujaque, A. Lledós, R. Malacea, E. Manoury, S. Vincendeau and R. Poli, ACS Catal. 2015, 5, 4368-4376 b) N. Gorgas, B. Stoeger, L. F. Veiros and K. Kirchner, ACS Catal. 2016, 6, 2664-2672; c) P. A. Dub, B. L. Scott and J. C. Gordon, J. Am. Chem Soc. 2017, 139, 1245-1260.

[21] a) I. Mellone, N. Gorgas, F. Bertini, M. Peruzzini, K. Kirchner and L. Gonsalvi, Organometallics 2016, 35, 3344-3349; b) E. Alberico, A. J. J. Lennox, L. K. Vogt, H. Jiao, W. Baumann, H.-J. Drexler, M. Nielsen, A. Spannenberg, M. P. Checinski, H. Junge and M. Beller, J. Am. Chem. Soc. 2016, 138, 14890-14904.

[22] a) P. A. Dub, N. J. Henson, R. L. Martin and J. C. Gordon, J. Am. Chem Soc. 2014, 136, 3505-3521; b) P. A. Dub and J. C. Gordon, ACS Catal. 2017, 7, 6635-6655.

[23] S. B. Jensen, S. J. Rodger and M. D. Spicer, J. Organomet. Chem. 1998 556, $151-158$.

[24] G. M. Sheldrick, Acta Cryst. A 2008, 64, 112-122.

[25] G. M. Sheldrick, Acta Crystallographica Section C-Structural Chemistry 2015, 71, 3-8.

[26] H. D. Flack, Acta Cryst. 1983, A39, 876-881.

[27] a) M. N. Burnett and C. K. Johnson, ORTEPIII, Report ORNL-6895. , Oak Ridge National Laboratory, Oak Ridge, Tennessee, U.S. , 1996, p; b) L. J. Farrugia, J. Appl. Cryst. 1997, 30, 565.

[28] Y. Zhao and D. G. Truhlar, J. Chem. Phys. 2006, 125, 194101.

[29] S. Grimme, J. Comput. Chem. 2006, 27, 1787-1799.

[30] M. J. Frisch, G. W. Trucks, H. B. Schlegel, G. E. Scuseria, M. A. Robb, J. R. Cheeseman, G. Scalmani, V. Barone, B. Mennucci, G. A. Petersson, H. Nakatsuji, M. Caricato, X. Li, H. P. Hratchian, A. F. Izmaylov, J. Bloino, G. Zheng, J. L. Sonnenberg, M. Hada, M. Ehara, K. Toyota, R. Fukuda, J. Hasegawa, M. Ishida, T. Nakajima, Y. Honda, O. Kitao, H. Nakai, T. Vreven, J. Montgomery, J. A., J. E. Peralta, F. Ogliaro, M. Bearpark, J. J. Heyd, E. Brothers, K. N. Kudin, V. N. Staroverov, R. Kobayashi, J. Normand, K. Raghavachari, A. Rendell, J. C. Burant, S. S. lyengar, J. Tomasi, M. Cossi, N. Rega, N. J. Millam, M. Klene, J. E. Knox, J. B. Cross, V. Bakken, C. Adamo, J. Jaramillo, R. Gomperts, R. E. Stratmann, O. Yazyev, A. J. Austin, R. Cammi, C. Pomelli, J. W. Ochterski, R. L. Martin, K. Morokuma, V. G. Zakrzewski, G. A. Voth, P. Salvador, J. J. Dannenberg, S. Dapprich, A. D. Daniels, Ö. Farkas, J. B. Foresman, J. V. Ortiz, J. Cioslowski and D. J. Fox, Gaussian 09, Revision D.01, Gaussian, Inc., Wallingford CT, 2009, p.

[31] M. Dolg, U. Wedig, H. Stoll and H. Preuss, J. Chem. Phys. 1987, 86, 866872.

[32] A. W. Ehlers, M. Böhme, S. Dapprich, A. Gobbi, A. Hoellwarth, V. Jonas, K. F. Koehler, R. Stegmann, A. Veldkamp and G. Frenking, Chem. Phys. Lett. 1993, 208, 111-114.

[33] R. Krishnan, J. S. Binkley, R. Seeger and J. A. Pople, J. Chem. Phys. $1980,72,650-654$

[34] A. V. Marenich, C. J. Cramer and D. G. Truhlar, J. Phys. Chem. B 2009 113, 6378-6396. 
Entry for the Table of Contents (Please choose one layout)

\section{FULL PAPER}

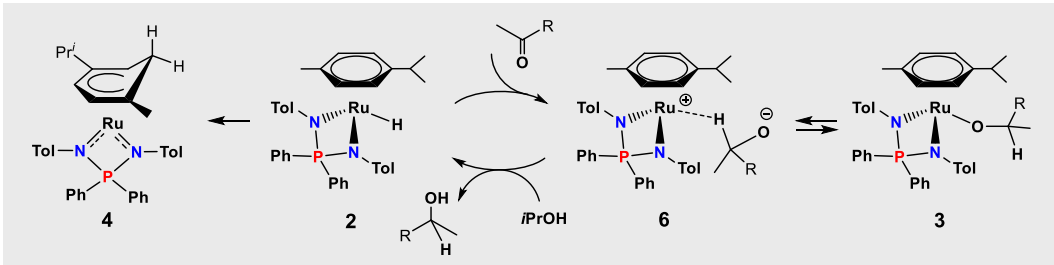

A highly reactive arene ruthenium iminophosphonamide hydride complex catalyses acetophenone transfer hydrogenation by isopropanol via a proposed zwitterionic intermediate and rearranges to a cyclohexadienyl 16-electron complex in the absence of substrate.

\section{Transfer Hydrogenation}

I. S. Sinopalnikova, T. A. Peganova, N. V. Belkova, E. Deydier, J.-C. Daran, E. S. Shubina, A. M. Kalsin, R. Poli *

Page No. - Page No.

Ruthenium p-cymene iminophosphonamide complexes: activation under basic conditions and transfer hydrogenation catalysis 